\title{
Application of Eh-pH Diagrams on Acid Leaching Systems for the Recovery of REEs from Bastnaesite, Monazite and Xenotime
}

\author{
Peijia Lin, Xinbo Yang ${ }^{(D}$, Joshua M. Werner* and Rick Q. Honaker \\ Department of Mining Engineering, University of Kentucky, Lexington, KY 40506, USA; peijia.lin@uky.edu (P.L.); \\ xinbo.yang@uky.edu (X.Y.); rick.honaker@uky.edu (R.Q.H.) \\ * Correspondence: joshua.werner@uky.edu
}

Citation: Lin, P.; Yang, X.; Werner, J.M.; Honaker, R.Q. Application of Eh-pH Diagrams on Acid Leaching Systems for the Recovery of REEs from Bastnaesite, Monazite and Xenotime. Metals 2021, 11, 734. https://doi.org/10.3390/met11050734

Academic Editor: Fiona M. Doyle

Received: 17 January 2021

Accepted: 21 April 2021

Published: 29 April 2021

Publisher's Note: MDPI stays neutral with regard to jurisdictional claims in published maps and institutional affiliations.

Copyright: (c) 2021 by the authors. Licensee MDPI, Basel, Switzerland. This article is an open access article distributed under the terms and conditions of the Creative Commons Attribution (CC BY) license (https:/ / creativecommons.org/licenses/by/ $4.0 /)$.

\begin{abstract}
Bastnaesite, monazite and xenotime are rare earth minerals (REMs) that are typical sources for rare earth elements (REEs). To advance the understanding of their leaching and precipitation behavior in different hydrometallurgical processes, Eh-pH diagrams were constructed and modified using the HSC 9.9 software. The aqueous stability of rare earth elements in $\mathrm{H}_{2} \mathrm{O}$ and acid leaching systems, i.e., the REE-Ligands- $\mathrm{H}_{2} \mathrm{O}$ systems, were depicted and studied based on the Eh-pH diagrams. This study considers the most relevant lixiviants, their resulting equilibrium states and the importance in the hydrometallurgical recovery of rare earth elements (REMs). A literature review was performed summarizing relevant Eh-pH diagrams and associated thermodynamic data. Shifting stability regions for REEs were discovered with additions of acid ligands and a narrow stability region for soluble REE-( $\left.\mathrm{SO}_{4} / \mathrm{Cl} / \mathrm{NO}_{3}\right)$ complexes under highly acidic conditions. As such, the recovery of REEs can be enhanced by adjusting $\mathrm{pH}$ and Eh values. In addition, the Eh-pH diagrams of the major contaminants (i.e., $\mathrm{Fe}, \mathrm{Ca}$ and $\mathrm{Al}$ ) in leaching systems were studied. The resulting Eh-pH diagrams provide possible insights into potential passivation on the particle surfaces due to the formation of an insoluble product layer.
\end{abstract}

Keywords: Eh-pH diagrams; rare earth minerals; rare earth elements; leaching; solution stability

\section{Introduction}

Rare earth elements (REEs) are indispensable constituents in many industrial applications including fuel cells, mobile phones, permanent magnets, lamp phosphors, rechargeable batteries and catalysts $[1,2]$. With the increasing demand and concerns over restricted or constricting supply, increased importance has been assigned to the improvement and recovery of REEs from REE-bearing minerals. The principal mineral sources for REEs are monazite, bastnaesite and xenotime [3]. In addition to the primary mineral sources, it has also become increasingly crucial to recycle REEs from end-of-life products, such as permanent magnets, fluorescent lamps, batteries and catalysts, which contain a fair amount of REEs [4-7]. REE primary and secondary sources are often treated with physical separation processes followed by hydrometallurgical methods. In broad terms, froth flotation is used to produce a REE mineral concentrate followed by leaching, solvent extraction and/or selective precipitation to extract the REEs from their mineral matrix $[3,8]$.

The behavior of REEs during leaching processes is typically evaluated using Eh-pH diagrams. Eh-pH diagrams, also known as Pourbaix diagrams, have played a significant role in understanding the aqueous stability of species that are thermodynamically stable within certain regions of redox potential and $\mathrm{pH}$. The application of Eh-pH diagrams is especially useful when multiple elements, which may interact with each other, co-exist in a solution. In addition, the study of Eh-pH diagrams can help improve the feasibility of the recovery/recycling of REEs by presenting the stable REE species in aqueous solutions regarding the critical processing conditions (i.e., $\mathrm{pH}$, Eh and acid ligands). The Eh-pH diagrams of rare earth metals were initially reported by Pourbaix in 1966 [9], which 
considered REEs only in an $\mathrm{H}_{2} \mathrm{O}$ system. Brookins (2012) [10] later presented the Eh-pH diagrams with REEs in carbonate systems in 1988. Hayes et al. (2002) [11] further studied the Eh-pH diagrams of cerium (Ce) species in $\mathrm{HClO}_{4}$ and $\mathrm{H}_{2} \mathrm{O}$ systems with updated thermodynamic data. The early studies of Eh-pH diagrams for REEs focused on their aqueous stability within simple systems, thereby lacking specific applications for more complex systems.

Recently, there have been several important additions to the aqueous stability of REEs that considered the effects of mineralogy. Kim et al. (2012) [12] established the Eh-pH diagrams of REEs in monazite during a hydrometallurgical process, which covered REE$\mathrm{H}_{2} \mathrm{O}$, REE-SO $\mathrm{S}_{4}-\mathrm{H}_{2} \mathrm{O}, \mathrm{REE}-\mathrm{PO}_{4}-\mathrm{H}_{2} \mathrm{O}$ and $\mathrm{REE}-\mathrm{PO}_{4}-\mathrm{SO}_{4}-\mathrm{H}_{2} \mathrm{O}$ systems, respectively. Their study of Th/ REE- $\mathrm{H}_{2} \mathrm{O}$ systems revealed notable differences between Th and REEs (Ce, $\mathrm{Nd}$ and $\mathrm{La}$ ). Eh-pH diagrams revealed that $\mathrm{Ce}^{3+}, \mathrm{Nd}^{3+}$ and $\mathrm{La}^{3+}$ have higher solubilities under slightly alkaline conditions while $\mathrm{Th}^{4+}$ only exists in strongly acidic conditions. The results show that most of the REEs (Ce, $\mathrm{Nd}$ and $\mathrm{La}$ ) exist stably in aqueous solutions in their trivalent or tetravalent ionic forms at neutral or acidic conditions. As $\mathrm{pH}$ increases to alkaline conditions $(\mathrm{pH}>7.5)$, the insoluble REE hydroxides $\left(\mathrm{Nd}(\mathrm{OH})_{3}, \mathrm{La}(\mathrm{OH})_{3}\right.$ and $\left.\mathrm{Ce}(\mathrm{OH})_{3}\right)$ start to form. This supports the theory of the separation between Th oxide (forms at $\mathrm{pH}>1.5$ ) and $\mathrm{REE}$ hydroxides by solution $\mathrm{pH}$ manipulation. Moreover, the insoluble product layer (Th oxide and REE hydroxides) may result in passivation on the mineral surface under alkaline conditions. In REE-( $\left.\mathrm{F} / \mathrm{PO}_{4}\right)-\mathrm{H}_{2} \mathrm{O}$ systems, REEs show a propensity to combine with $\mathrm{PO}_{4}{ }^{3-}$ and $\mathrm{F}^{-}$to form insoluble rare earth phosphates or fluorides within certain $\mathrm{pH}$ ranges. Similarly, in REE- $\mathrm{H}_{2} \mathrm{O}$ systems, Th and REEs (Ce, Nd and La) in REE$\left(\mathrm{F} / \mathrm{PO}_{4}\right)-\mathrm{H}_{2} \mathrm{O}$ systems form insoluble products at various $\mathrm{pH}$ values. REE phosphates form at $\mathrm{pH}>6$ while Th phosphate occurs at $\mathrm{pH}>0$. Thermodynamic data of REE species with suspected variations in crystallinities were applied and the resulting Eh-pH diagrams were compared in Kim's study. The comparison between the stabilities of REE phosphates with different crystalline forms revealed the relationship between monazite dissolution and its crystallinity. It was suggested that naturally occurring monazite ores are more crystalline with higher chemical stability, and less easily dissolved in acid owing to the higher bond energy. Moreover, Kim et al. (2012) [12] examined the effect of sulfate $\left(\mathrm{SO}_{4}{ }^{2-}\right)$ concentrations on the stability regions of REEs. In REE-SO $\mathrm{S}_{4}-\mathrm{H}_{2} \mathrm{O}$ and REE- $\mathrm{PO}_{4}-\mathrm{SO}_{4}-\mathrm{H}_{2} \mathrm{O}$ systems, $\mathrm{SO}_{4}{ }^{2-}$ combines with REEs as a complexing ligand that favors the stabilization of REE-SO ${ }_{4}$ compounds in solution. In the Eh-pH diagrams by Kim et al., the stability domains of insoluble REE products (REE oxides, REE hydroxides, REE phosphates and REE sulfates) diminished as the $\mathrm{SO}_{4}{ }^{2-}$ concentration increased. Meanwhile, the stability regions of soluble $\mathrm{Th} / \mathrm{Ce}-\mathrm{SO}_{4}$ complexes extended with increasing $\mathrm{SO}_{4}{ }^{2-}$ concentration but decreased with an elevation in temperature. Their results are well aligned with the decomposition of monazite in sulfuric acid lixiviants.

Shuai et al. (2017) [13] studied the aqueous equilibrium of bastnaesite in hydrochloric acid leaching systems. Their results showed that trivalent REEs $\left(\mathrm{REE}^{3+}\right)$ are stable in leaching solutions at a certain acidity $(\mathrm{pH}<2)$, while tetravalent cerium and thorium $\left(\mathrm{Ce}^{4+} / \mathrm{Th}^{4+}\right)$ remain in solid forms. The Eh-pH diagrams in the $\mathrm{REE} / \mathrm{Th}-\mathrm{Cl}-\mathrm{H}_{2} \mathrm{O}$ system indicate that trivalent REE ions $\left(\mathrm{REE}^{3+}\right)$ leach into solution at $\mathrm{pH}$ values below 6 , whereas $\mathrm{Ce}^{4+}$ and $\mathrm{Th}^{4+}$ require $\mathrm{pH}$ values below 0 and 2 , respectively. At $\mathrm{pH}$ values below 0 , $\mathrm{Ce}^{4+}$ can be partially reduced to $\mathrm{Ce}^{3+}$ to form $\mathrm{CeF}_{3}$ precipitates when $\mathrm{F}^{-}$is present. This result indicates that the separation between $\mathrm{REE}^{3+}$ and $\mathrm{Ce}^{4+} / \mathrm{Th}^{4+}$ can be achieved by manipulating the $\mathrm{pH}$ during leaching, which agrees with the leaching data presented later in this study. In addition, Al-Nafai (2015) [14] studied the Eh-pH diagrams of bastnaesite in nitric acid systems. $\mathrm{CeNO}_{3}{ }^{2+}, \mathrm{LaNO}_{3}{ }^{2+}$ and $\mathrm{NdNO}_{3}{ }^{2+}$ were found to be stable species in their trivalent state under neutral to acidic conditions with nitrate ions. As the concentration of nitric acid decreases, the stability regions of $\mathrm{REE}-\mathrm{NO}_{3}$ species narrow and eventually disappear from the corresponding Eh-pH diagrams due to the lack of nitrate ions. REEs exist in a soluble form as nitrates below $\mathrm{pH} 2$ and precipitate in sequence as fluorides, fluorine-carbonates and hydroxides, respectively, as the solution $\mathrm{pH}$ is increased. 
Agarwal et al. (2018) [15] studied monazite and bastnaesite systems with a focus on the yttrium (Y) species in sulfate, nitrate and chloride solutions. The results showed that free $\mathrm{Y}^{3+}$ ions are dominant in all considered systems below $\mathrm{pH} 5$ while $\mathrm{YSO}_{4}{ }^{+}$and $\mathrm{YCl}^{2+}$ co-exist with $\mathrm{Y}^{3+}$ in the matrix of sulfuric and hydrochloric acids, respectively. Eh-pH diagrams were also compared with speciation diagrams, which depicted the distribution of the $\mathrm{Y}$ species in solution as a function of $\mathrm{pH}$ at a constant Eh value. The findings from the speciation and Eh-pH diagrams were consistent. Although Agarwal's work revealed the aqueous speciation of yttrium after acid leaching, further speciation investigations are needed to describe the leaching and precipitation processes.

The objective of this study was to determine, from the literature, the appropriate thermodynamic values required to construct Eh-pH diagrams for systems not previously studied and, by so doing, promote a deeper understanding of the dissolution and precipitation processes that are critical to the extraction of REEs from RE minerals. It is anticipated that this work will provide insights into the processing of a wide variety of primary and secondary REE sources. As an example of secondary sources, other researchers found that coal and coal byproducts could be a promising alternative source for REEs [16-19]. RE phosphate minerals (apatite, monazite and xenotime) are discovered as most commonly presented rare earth mineral in coal sources [20-22]. There is also evidence to support the presence of ion-exchangeable REEs in coal byproducts $[23,24]$. To investigate the thermodynamic aqueous equilibrium of several pertinent systems, literature was consulted for the appropriate elements combined with the associated lixiviant. As shown in Table 1, there have been significant contributions made in the domains of interest. This work will seek to explore the equilibrium data needed to study the effects on leaching and precipitation based on the data from previous leaching tests (as shown in Table 2).

Table 1. Eh-pH diagrams of three minerals in different acid leaching systems.

\begin{tabular}{|c|c|c|c|}
\hline Lixiviant & $\begin{array}{c}\text { Bastnaesite } \\
(\mathrm{Ce}, \mathrm{La})\left(\mathrm{CO}_{3}\right) \mathrm{F}\end{array}$ & $\begin{array}{c}\text { Monazite } \\
(\mathrm{Ce}, \mathrm{La}, \mathrm{Nd}, \mathrm{Th}) \mathrm{PO}_{4}\end{array}$ & $\begin{array}{l}\text { Xenotime } \\
\mathrm{YPO}_{4}\end{array}$ \\
\hline $\mathrm{H}_{2} \mathrm{SO}_{4}$ & Current Study & Kim et al. [12] & \multirow{3}{*}{$\begin{array}{c}\text { Agarwal et al. [15] } \\
\text { and } \\
\text { Current Study }\end{array}$} \\
\hline $\mathrm{HCl}$ & Shuai et al. [13] & Current Study & \\
\hline $\mathrm{HNO}_{3}$ & Al-Nafai [14] & Current Study & \\
\hline
\end{tabular}

Table 2. Parameters in the acid leaching tests reported in this study.

\begin{tabular}{|c|c|c|c|c|c|c|c|}
\hline Materials & Acid Type & $\begin{array}{c}\text { Acid } \\
\text { Conc.(M) }\end{array}$ & $\begin{array}{c}\text { Stirring } \\
\text { Speed (rpm) }\end{array}$ & Temperature(K) & $\begin{array}{l}\text { S/L Ratio } \\
\text { (g/L) }\end{array}$ & $\begin{array}{l}\text { Time } \\
\text { (min) }\end{array}$ & $\begin{array}{c}\text { Particle Size } \\
(<\text { mesh })\end{array}$ \\
\hline $\begin{array}{l}\text { Pure minerals } \\
\text { (monazite, } \\
\text { bastnaesite, } \\
\text { xenotime) }\end{array}$ & $\begin{array}{c}\mathrm{H}_{2} \mathrm{SO}_{4}, \mathrm{HCl} \\
\mathrm{HNO}_{3}\end{array}$ & 1.0 & 530 & 298 & 10 & $\begin{array}{c}5,15,30,60 \\
90,120\end{array}$ & 80 \\
\hline
\end{tabular}

The highlights of this study are as follows:

- A review of existing research on Eh-pH diagrams and thermodynamic data of REELigands- $\mathrm{H}_{2} \mathrm{O}$ systems;

- Development of Eh-pH diagrams for Bastnaesite- $\mathrm{H}_{2} \mathrm{SO}_{4}$, Monazite-HCl, Monazite$\mathrm{HNO}_{3}$ and Xenotime- $\mathrm{H}_{2} \mathrm{SO}_{4} / \mathrm{HCl} / \mathrm{HNO}_{3}$ systems;

- A possible explanation for low Ce recoveries and passivation in tested monazite minerals;

- A likely reason for the lower performance of $\mathrm{HCl}$ lixiviant compared to $\mathrm{HNO}_{3}$ and $\mathrm{H}_{2} \mathrm{SO}_{4}$ for bastnaesite leaching. 


\section{Materials and Methods}

\subsection{Rare Earth Minerals in Leaching Systems}

Bastnaesite, monazite and xenotime account for the majority of the REE production from a variety of recognized RE ores [8,25]. For the construction of Eh-pH diagrams, these three minerals are considered as the likely dominant RE sources and thus were the focus in the construction of the corresponding Eh-pH diagrams for the $\mathrm{RE}$ minerals-ligands- $\mathrm{H}_{2} \mathrm{O}$ systems during acid leaching. The major species studied in the leaching of bastnaesite (chemical formula: $\left.(\mathrm{Ce}, \mathrm{La})\left(\mathrm{CO}_{3}\right) \mathrm{F}\right)$ are $\mathrm{Ce}$, La and F. Monazite (chemical formula: $(\mathrm{Ce}$, $\mathrm{La}, \mathrm{Nd}, \mathrm{Th}) \mathrm{PO}_{4}$ ) is a $\mathrm{RE}$ phosphate mineral with a relatively high HREE composition compared to bastnaesite [8]. The Eh-pH diagrams for monazite leaching focused on the $(\mathrm{Ce} / \mathrm{La} / \mathrm{Nd} / \mathrm{Th})-\mathrm{PO}_{4}$-Ligands- $\mathrm{H}_{2} \mathrm{O}$ systems. Xenotime (chemical formula: $\mathrm{Y}\left(\mathrm{PO}_{4}\right)$ ), unlike bastnaesite and monazite, is particularly enriched in large quantities of yttrium and other heavy rare earth elements. The development of the Eh-pH diagrams for xenotime leaching systems consist mostly of yttrium and acid ligands in $\mathrm{H}_{2} \mathrm{O}$ and an objective of the study.

Concentrate samples of the three RE minerals (bastnaesite, monazite and xenotime) were obtained from the Mineralogical Research Company (San Jose, CA, USA) and used in leaching experiments to provide data for comparison with the Eh-pH diagrams. The monazite sample, which originated from Eureka Farm 99 (Stiplemans mine operation), Namibia, contained about $10 \%$ total REEs, including $5.7 \% \mathrm{Ce}, 3.2 \% \mathrm{La}$, and $1.0 \% \mathrm{Nd}$, while the other REEs accounted for less than $0.1 \%$. As such, the chemical formula representing the mineral type is most likely $\left(\mathrm{Ce}_{0.6} \mathrm{La}_{0.3} \mathrm{Nd}_{0.1}\right) \mathrm{PO}_{4}$. The bastnaesite sample $\left(\left(\mathrm{Ce}_{0.5} \mathrm{La}_{0.25} \mathrm{Nd}_{0.25}\right) \mathrm{CO}_{3} \mathrm{~F}\right)$ was mined from Oregon No. 2 pegmatite from an operation located in Jefferson County, CO. The sample contained 25\% total REEs (TREEs), which included $12.5 \% \mathrm{Ce}, 4.3 \% \mathrm{La}$, $4.3 \% \mathrm{Nd}$ and significantly smaller quantities of the other light REEs. The xenotime sample was a product of a mine located in Norway and contained 5.5\% yttrium, which accounted for over $63 \%$ of the TREEs. Thorium was the second highest, representing $2.5 \%$ by weight of the total.

\subsection{Leaching Procedures}

The mineral samples were crushed and ground in a shatter box to a top size of 15 microns. Leaching experiments were conducted using a triple neck round bottom flask with a total reflux condenser. Temperature was maintained using a water bath at $25^{\circ} \mathrm{C}$. Agitation was provided using a magnetic stirrer at $530 \mathrm{rpm}$. Leaching experiments were carried out using $1 \mathrm{M} \mathrm{H}_{2} \mathrm{SO}_{4}, 1 \mathrm{M} \mathrm{HCl}$ and $1 \mathrm{M} \mathrm{HNO}_{3}$ aqueous solutions with $10 \mathrm{~g} / \mathrm{L}$ solids concentration. Slurry samples were collected at the following times after test initiation: 5, 15, 30, 60, 90 and $120 \mathrm{~min}$. The solids and liquid samples were immediately separated within one minute of collection using a micro filter. Elemental recovery was calculated using the following expression:

$$
R(\%)=\frac{c_{L} \times V_{L}}{c_{f} \times m_{f}} \times 100
$$

where $c_{L}$ is the elemental concentration in the leachate, $V_{L}$ is the leachate volume, $c_{f}$ is the concentration in feed, and $m_{f}$ is the mass of the feed solids.

\subsection{Construction of Eh-pH Diagrams Using the HSC Software}

To simulate the leaching conditions in $\mathrm{H}_{2} \mathrm{SO}_{4}, \mathrm{HNO}_{3}$ and $\mathrm{HCl}$ systems, the concentrations of the elements (i.e., $\mathrm{S} / \mathrm{Cl} / \mathrm{N}$ ) that form the corresponding acid ligands (i.e., $\mathrm{SO}_{4} / \mathrm{Cl} / \mathrm{NO}_{3}$ ) were input as $1 \mathrm{M}$ when constructing the Eh-pH diagrams. The Eh-pH diagrams were generated using HSC 9.9 under $25^{\circ} \mathrm{C}$ and 1 bar. The Eh value is presented as relative to the Standard Hydrogen Electrode (SHE) potential. Due to higher temperatures decreasing the solubilities of RE phosphates, the temperature was held constant at $25^{\circ} \mathrm{C}$ when constructing the Eh-pH diagrams and comparing different chemical systems. The molarities of REEs were calculated based on the concentrations from the chemical assay. 


\section{Results and Discussions}

\subsection{Leaching of REE-Bearing Minerals}

As the main component in monazite and bastnaesite minerals, Ce has the ability of changing its valence between +3 and +4 . The recovery of Ce is thereby more complicated than that of other REEs in leaching solutions. Efforts were made to leach Ce from pure RE minerals, and the results of Ce recoveries were discussed in this study for monazite and bastnaesite leaching. The results of applying different lixiviants on recovering Ce from monazite are shown in Figure 1. The recoveries of $\mathrm{Ce}$ in $1 \mathrm{M} \mathrm{H}_{2} \mathrm{SO}_{4}, 1 \mathrm{M} \mathrm{HCl}$ and $1 \mathrm{M}$ $\mathrm{HNO}_{3}$ were only $0.5,0.7$ and $0.7 \%$, respectively. Based on the Eh-pH diagrams produced for the REE- $\mathrm{PO}_{4}-\mathrm{SO}_{4}-\mathrm{H}_{2} \mathrm{O}$ system by Kim et al. [12], a surface reaction involving the hydrated insoluble forms of $\mathrm{Nd}$ and La may create a product layer that prevents the additional leaching of $\mathrm{Ce}$ in the $\mathrm{H}_{2} \mathrm{SO}_{4}$ leaching system. This hypothesis could possibly explain the low $\mathrm{Ce}$ recovery-less than $0.4 \%$ when using $\mathrm{H}_{2} \mathrm{SO}_{4}$ as a lixiviant (Figure 1 ).

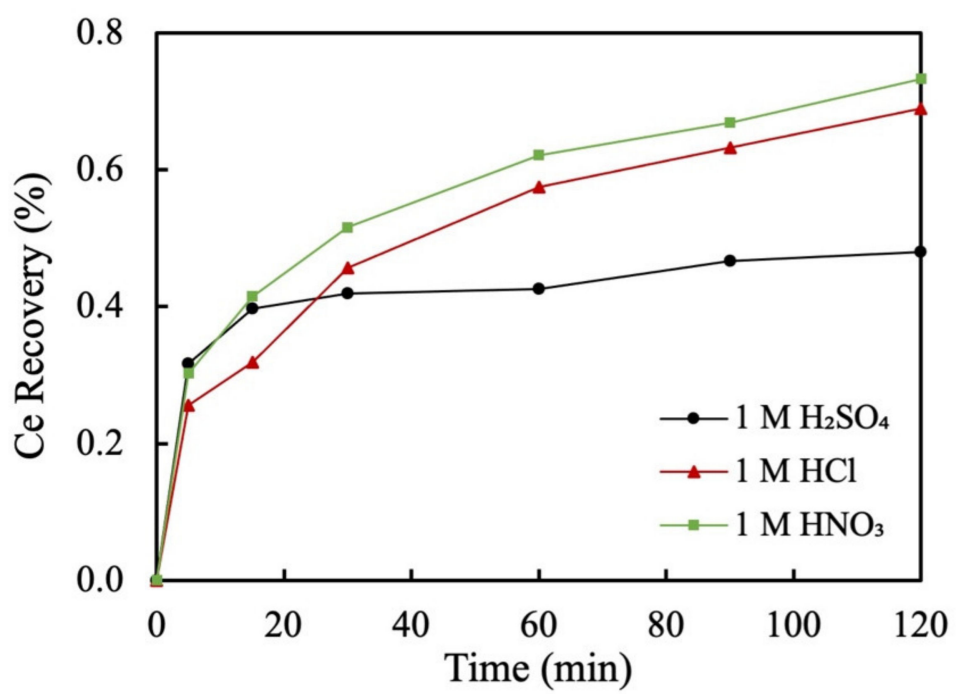

Figure 1. Recovery of Ce from pure monazite using different lixiviants at $25{ }^{\circ} \mathrm{C}$ and a solids concentration of $10 \mathrm{~g} / \mathrm{L}$.

To further investigate the existing species in solution, the speciation diagram for $\mathrm{Ce}^{3+}$ in the $\mathrm{Ce}-\mathrm{SO}_{4}-\mathrm{H}_{2} \mathrm{O}$ system was plotted using data obtained from Visual MINTEQ 3.1 (KTH, Stockholm, Sweden), as shown in Figure 2. Due to the lack of roasting or strong oxidative conditions, the formation of $\mathrm{Ce}^{4+}$ in the aqueous system is not anticipated. For that reason, only $\mathrm{Ce}^{3+}$ species (i.e., $\mathrm{Ce}\left(\mathrm{SO}_{4}\right)_{2}{ }^{-}, \mathrm{Ce}^{3+}, \mathrm{CeOH}^{2+}$ and $\left.\mathrm{CeSO}_{4}{ }^{+}\right)$are considered in Figure 2. The dominant $\mathrm{Ce}$ species that exist in the given system are cerium sulfate complexes, i.e., $\mathrm{Ce}\left(\mathrm{SO}_{4}\right)_{2}{ }^{-}$and $\mathrm{CeSO}_{4}{ }^{+}$. As the concentration of $\mathrm{SO}_{4}{ }^{2-}$ increases, the distribution percentage of $\mathrm{Ce}\left(\mathrm{SO}_{4}\right)_{2}{ }^{-}$increases, while the distribution percentages of $\mathrm{CeSO}_{4}{ }^{+}, \mathrm{Ce}^{3+}$, and $\mathrm{CeOH}^{2+}$ decrease. Under a $\mathrm{SO}_{4}{ }^{2-}$ concentration of $0.1 \mathrm{M}, \mathrm{Ce}\left(\mathrm{SO}_{4}\right)_{2}{ }^{-}$ and $\mathrm{CeSO}_{4}{ }^{+}$are equally distributed. $\mathrm{At}_{\mathrm{SO}_{4}}{ }^{2-}$ concentrations higher than $0.1 \mathrm{M}, \mathrm{Ce}\left(\mathrm{SO}_{4}\right)_{2}{ }^{-}$ is predominant in the solution. This result shows consistency with the Eh- $\mathrm{pH}$ diagrams for the $\mathrm{Ce}-\mathrm{SO}_{4}-\mathrm{H}_{2} \mathrm{O}$ system reported by Kim et al., where $\mathrm{CeSO}_{4}{ }^{+}$is the predominant species at $\mathrm{SO}_{4}{ }^{2-}=0.1 \mathrm{M}$ and decreases dramatically at $\mathrm{SO}_{4}{ }^{2-}=1.0 \mathrm{M}$ [12]. 


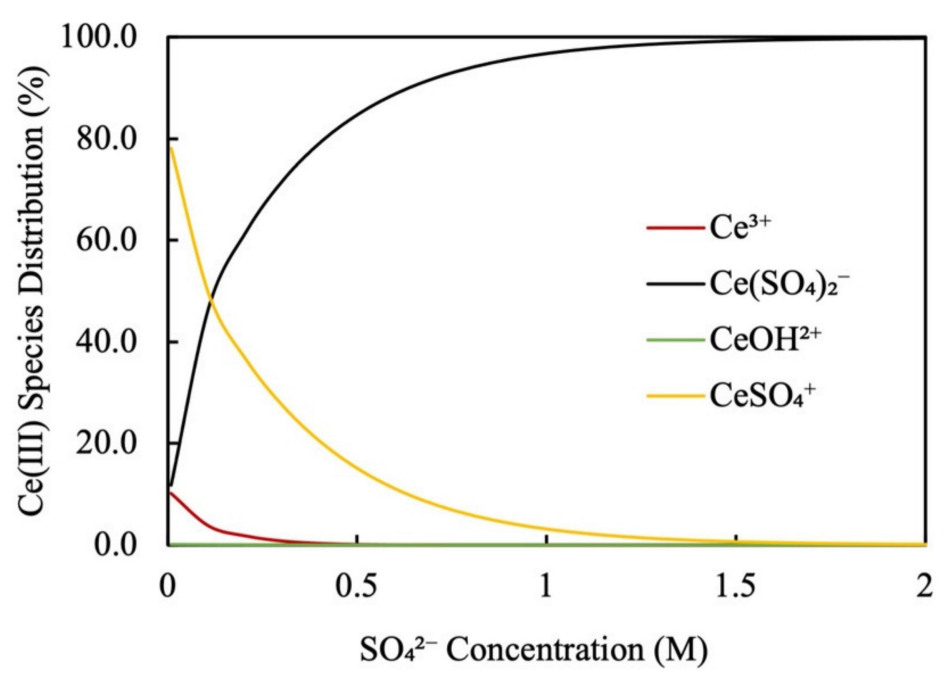

Figure 2. $\mathrm{Ce}^{3+}$ speciation in the $\mathrm{Ce}-\mathrm{SO}_{4}-\mathrm{H}_{2} \mathrm{O}$ system over a range of sulfate concentrations at $25{ }^{\circ} \mathrm{C}$ : $\mathrm{SO}_{4}{ }^{2-}$ from 0.01 to $2 \mathrm{M}, \mathrm{Ce}^{3+}=10^{-3} \mathrm{M}$ (calculated using the Visual MINTEQ 3.1 software).

The leaching results of $\mathrm{Ce}$ from bastnaesite are shown in Figure 3. Improved recoveries are observed in $1 \mathrm{M} \mathrm{HNO}_{3}$ and $1 \mathrm{M} \mathrm{H}_{2} \mathrm{SO}_{4}$, whereas the recovery in $1 \mathrm{M} \mathrm{HCl}$ leaching is comparatively lower. According to research performed by Shuai et al. [13], $\mathrm{Ce}^{4+}$ and $\mathrm{F}^{-}$mainly exist as $\left[\mathrm{CeF}_{2}\right]^{2+}$ in sulfuric acid. The cumulative stability constant of $\left[\mathrm{CeF}_{2}\right]^{2+}$ is higher than the solubility product constant value of $\mathrm{REEF}_{3}$. The stronger coordination between $\mathrm{Ce}^{4+}$ and $\mathrm{F}^{-}$result in the formation of soluble complexes in solution. However, as reported by Shuai et al., $\mathrm{Ce}^{4+}$ is reduced to $\mathrm{Ce}^{3+}$ during acid leaching and the latter forms insoluble $\mathrm{CeF}_{3}$ with free $\mathrm{F}^{-}$ions [13], which explains the low recovery of $\mathrm{Ce}$ in our $\mathrm{HCl}$ leaching tests when compared to other lixiviants as presented in Figure 3.

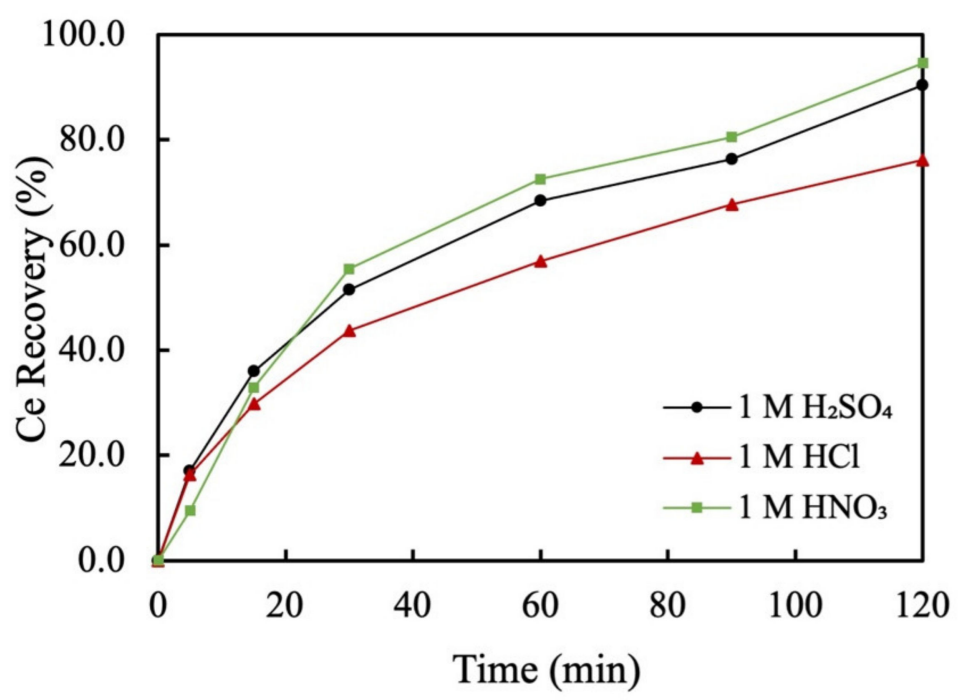

Figure 3. Recovery of Ce in bastnaesite leaching with various lixiviants at $25^{\circ} \mathrm{C}$ with $10 \mathrm{~g} / \mathrm{L}$ solid concentration.

The leaching performance of xenotime in different lixiviants shown in Figure 4 revealed characteristics similar to those of monazite due to the similarities in the mineral crystal structure. The recoveries of $\mathrm{Y}$ in xenotime were 17,8 and $11 \%$ using $1 \mathrm{M} \mathrm{H}_{2} \mathrm{SO}_{4}$, $1 \mathrm{M} \mathrm{HCl}$, and $1 \mathrm{M} \mathrm{HNO}_{3}$, respectively. $\mathrm{H}_{2} \mathrm{SO}_{4}$ leaching provided the highest yttrium recovery, which may be due to the complexation of sulfate ions to $\mathrm{Y}$. The speciation stability of $\mathrm{Ce}$ and $\mathrm{Y}$ with $\mathrm{SO}_{4}{ }^{2-}, \mathrm{Cl}^{-}$and $\mathrm{NO}_{3}{ }^{-}$in aqueous solutions are further discussed in the following sections. 


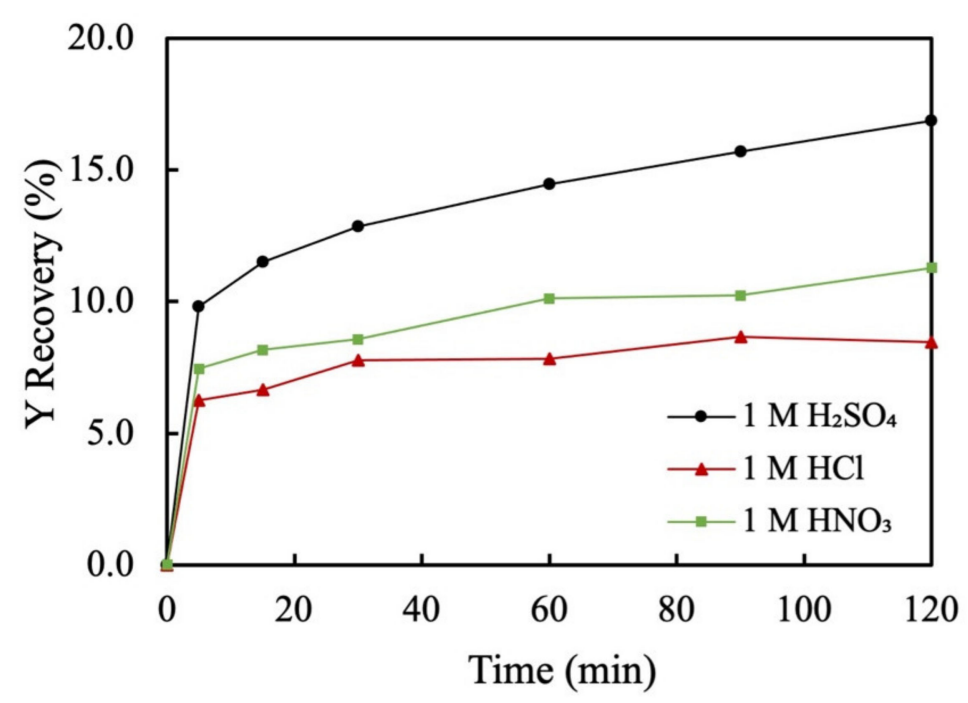

Figure 4. Recovery of $\mathrm{Y}$ in xenotime leaching with various lixiviants at $25^{\circ} \mathrm{C}$ with $10 \mathrm{~g} / \mathrm{L}$ solid concentration.

\subsection{Eh-pH Diagrams of Rare Earth Mineral Leachates}

To address the systems that have not been previously studied (Table 1), the Eh-pH diagrams of bastnaesite leaching in a $\mathrm{H}_{2} \mathrm{SO}_{4}$ system, monazite in $\mathrm{HCl}$ and $\mathrm{HNO}_{3}$ systems and xenotime in $\mathrm{H}_{2} \mathrm{SO}_{4}, \mathrm{HCl}$ and $\mathrm{HNO}_{3}$ systems were investigated. The results and discussions are provided in the following sections.

\subsubsection{Bastnaesite Leaching}

Bastnaesite (chemical formula: $\left.(\mathrm{Ce}, \mathrm{La})\left(\mathrm{CO}_{3}\right) \mathrm{F}\right)$ is a major REE-bearing mineral [26]. The primary species in bastnaesite leachate are $\mathrm{Ce}$, La and $\mathrm{F}$, with the corresponding acid ligands in the lixiviants. In most hydrometallurgical processes, bastnaesite is typically roasted under conditions that eliminate carbonate. Therefore, when constructing the Eh- $\mathrm{pH}$ diagrams for bastnaesite leaching, $\mathrm{CO}_{3}{ }^{2-}$ is excluded from the system due to the removal of carbonates or the lack of carbonate compounds.

The concentration of the element $\mathrm{S}$ composing the acid ligand (i.e., $\mathrm{SO}_{4}{ }^{2-}$ ) was $1 \mathrm{M}$ for the construction of the Eh-pH diagrams of bastnaesite leaching in a $\mathrm{H}_{2} \mathrm{SO}_{4}$ system. The molarities of REEs were calculated based on a chemical assay. The Eh-pH diagrams were generated using HSC 9.9 under $25^{\circ} \mathrm{C}$ and 1 bar as presented in Figures 5-7.

As previously shown in Figure 3, the recovery of Ce in bastnaesite reaches 90, 76 and $94 \%$ after $2 \mathrm{~h}$ of leaching using $1 \mathrm{M} \mathrm{H}_{2} \mathrm{SO}_{4}, 1 \mathrm{M} \mathrm{HCl}$, and $1 \mathrm{M} \mathrm{HNO}_{3}$, respectively. Due to the effect of $\mathrm{Ce}^{4+}$ and $\mathrm{Ce}^{3+}$ on the system, several Eh-pH diagrams are proposed (refer to the bastnaesite summary in Table 1). In a system where bastnaesite is roasted and oxidized, it may be assumed that $\mathrm{Ce}$ mainly exists as a tetravalent species. As shown in Figure 5, $\mathrm{Ce}^{4+}$ forms a hydrated $\mathrm{Ce}\left(\mathrm{SO}_{4}\right)_{2}$ salt, which dominates the water stability region. Anecdotal evidence of the lack of solubility of $\mathrm{Ce}^{4+}$ compounds is corroborated by processes that roast bastnaesite to selectively leach other REEs. It was found in literature that ionic Ce $\left(\mathrm{Ce}^{3+}\right.$ and $\left.\mathrm{Ce}^{4+}\right)$ has a strong ability to coordinate with $\mathrm{F}^{-}$and forms a Ce-F complex in the presence of sulfuric acid [14]. The possible existence of a Ce-F complex is indicated by the light blue stability region of $\mathrm{CeF}_{3}$ below the lower water stability line in the Eh-pH diagram (Figure 5). However, the stability region of $\mathrm{CeF}_{3}$ was overlapped by $\mathrm{Ce}\left(\mathrm{SO}_{4}\right)_{2} \cdot 5 \mathrm{H}_{2} \mathrm{O}$ within the water stability region due to its lower stability compared to $\mathrm{Ce}\left(\mathrm{SO}_{4}\right)_{2} \cdot 5 \mathrm{H}_{2} \mathrm{O}$. It seems that, when $\mathrm{Ce}-\mathrm{F}$ and $\mathrm{Ce}-\mathrm{SO}_{4}$ compounds co-exist in the system, $\mathrm{Ce}^{4+}$ tends to complex with $\mathrm{SO}_{4}{ }^{2-}$ in the form of $\mathrm{Ce}\left(\mathrm{SO}_{4}\right)_{2}$ with excess $\mathrm{SO}_{4}{ }^{2-}$ ions. 
Although Figure 5 suggests a solid form as a $\mathrm{Ce}^{-\mathrm{SO}_{4}}$ complex at equilibrium in the presence of $\mathrm{Ce}^{4+}$, the leaching recovery shown in Figure 3 indicates that $\mathrm{Ce}$ is soluble at low $\mathrm{pH}$ values of around 0 in a $1 \mathrm{M} \mathrm{H}_{2} \mathrm{SO}_{4}$ solution. Due to the variance between the experimental results in Figure 3 showing excellent solubility of cerium from unroasted bastnaesite and the theoretical Eh-pH diagram proposed in Figure 5 indicating an insoluble form of cerium, the Eh-pH diagram was modified to exclude $\mathrm{Ce}\left(\mathrm{SO}_{4}\right)_{2} \cdot 5 \mathrm{H}_{2} \mathrm{O}$ while holding all other parameters constant. The reason to discount the $\mathrm{Ce}^{4+}$ species (i.e., $\mathrm{Ce}\left(\mathrm{SO}_{4}\right)_{2} \cdot 5 \mathrm{H}_{2} \mathrm{O}$ ) is that, due to the lack of pre-roasting/pre-oxidizing or the addition of a strong oxidizer, it is unlikely that $\mathrm{Ce}^{4+}$ will form across the water stability region, even under highly acidic and oxidative conditions. The modified Eh- $\mathrm{pH}$ diagram of the Ce-F- $\mathrm{SO}_{4}-\mathrm{H}_{2} \mathrm{O}$ system is shown in Figure 6. Without the formation of $\mathrm{Ce}\left(\mathrm{SO}_{4}\right)_{2} \cdot 5 \mathrm{H}_{2} \mathrm{O}$, the stability region of $\mathrm{Ce}^{3+}$ occurs within a $\mathrm{pH}$ range of -2 to 2 . The change of Ce species in the modified Eh-pH diagram shows that $\mathrm{Ce}$ could exist stably in its ionic $\mathrm{Ce}^{3+}$ form at $\mathrm{pH}$ values lower than 2 in a $1 \mathrm{M} \mathrm{H}_{2} \mathrm{SO}_{4}$ leaching system in the absence of $\mathrm{Ce}^{4+}$. This comparison is significant in that the oxidization state of Ce appears to be the single most important factor in the propensity to leach with the associated impact of the oxidation rate of Ce in aqueous systems and the Eh of the solution. In summary, the un-oxidized bastnaesite-sulfate system is better described by the Eh-pH diagram of Figure 6 rather than the more exact thermodynamic predictions presented in Figure 5 given the timescale of the leach test that provided the recovery values presented in Figure 3.

Lanthanum, as shown in Figure 7, also has the ability of complexing with $\mathrm{F}^{-}$and forms insoluble $\mathrm{LaF}_{3}$. However, the La-SO $\mathrm{SO}_{4}$ compound is soluble in the water stability region within the $\mathrm{pH}$ range of 1.5 to 8.5 . This finding suggests promising La leachability in sulfuric acid systems for bastnaesite leaching.

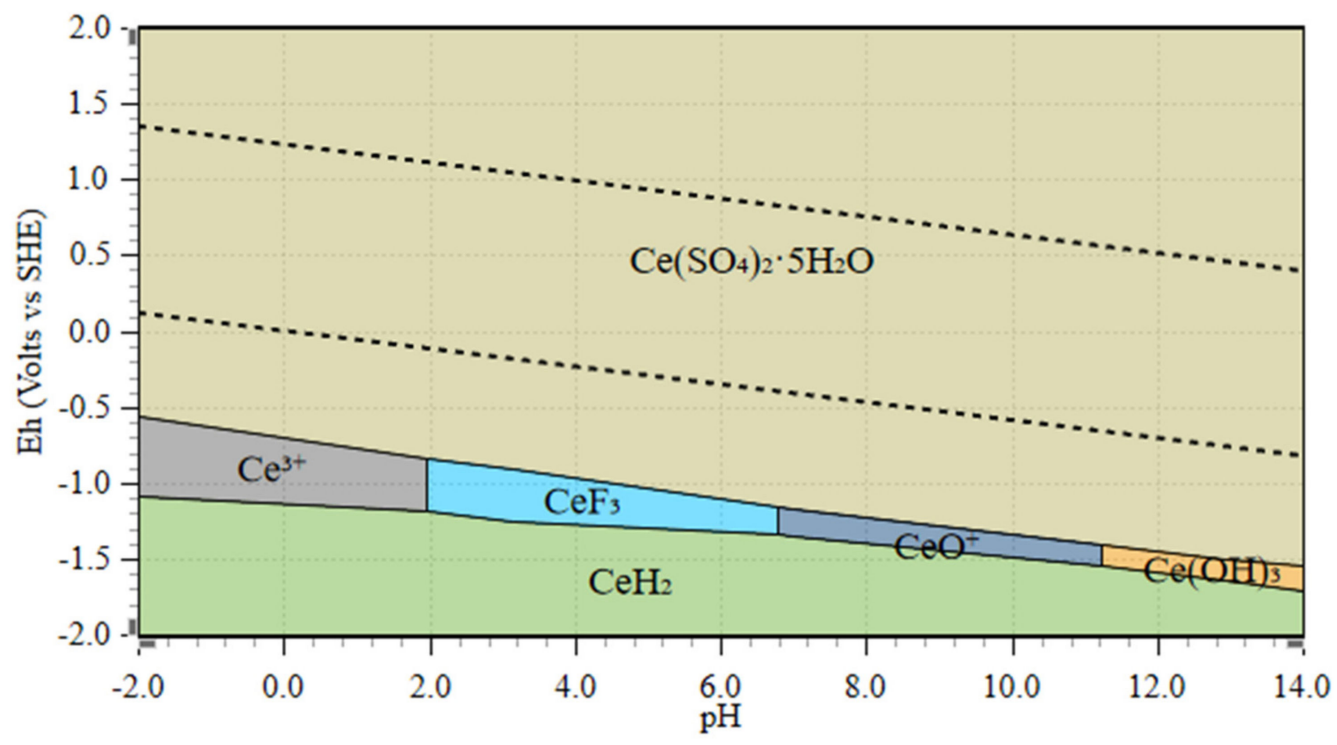

Figure 5. Eh-pH diagram of the Ce-F-SO $-\mathrm{H}_{4} \mathrm{O}$ system for bastnaesite leaching in $\mathrm{H}_{2} \mathrm{SO}_{4}$ at $25{ }^{\circ} \mathrm{C}$ : $\mathrm{Ce}=10^{-3} \mathrm{M}, \mathrm{F}=10^{-3} \mathrm{M}, \mathrm{S}=1.0 \mathrm{M}$. 


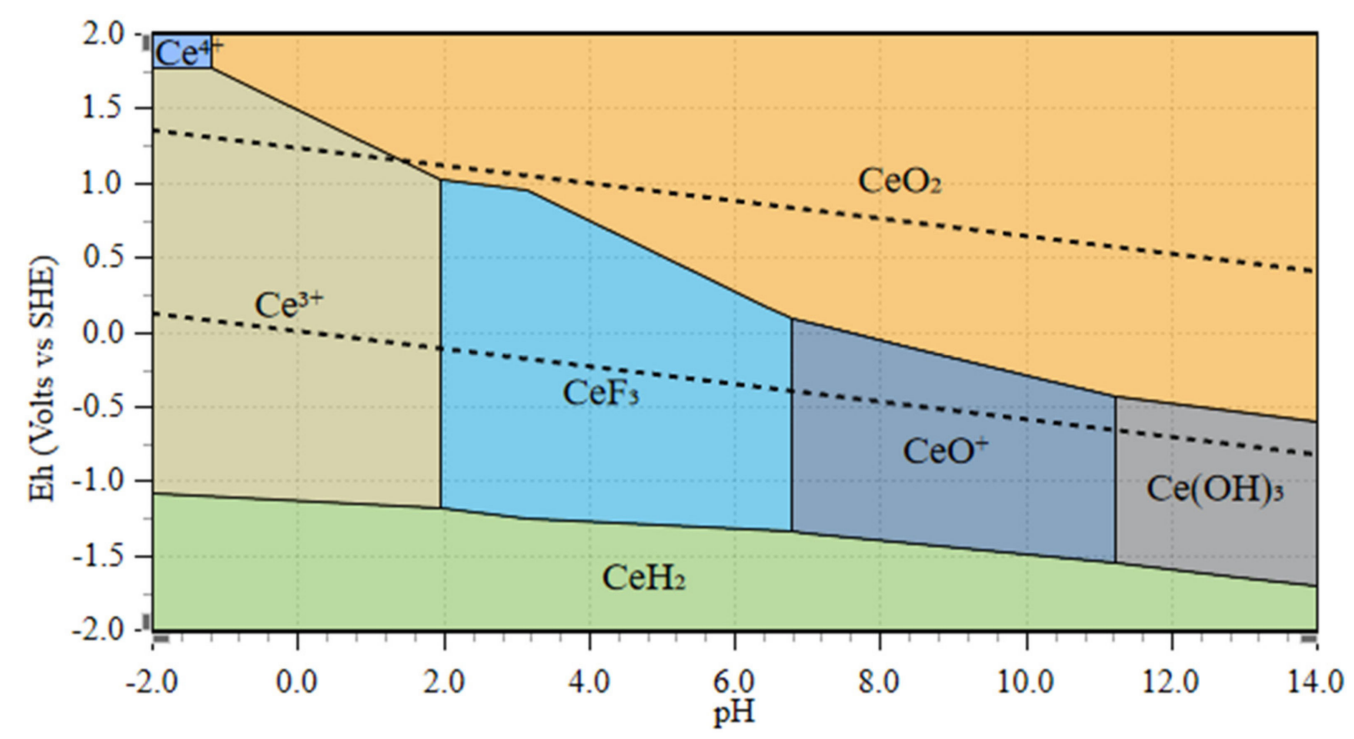

Figure 6. Modified Eh-pH diagram of the Ce-F-SO $\mathrm{SO}_{4}-\mathrm{H}_{2} \mathrm{O}$ system for bastnaesite leaching in $\mathrm{H}_{2} \mathrm{SO}_{4}$ at $25^{\circ} \mathrm{C}: \mathrm{Ce}=10^{-3} \mathrm{M}, \mathrm{F}=10^{-3} \mathrm{M}, \mathrm{S}=1.0 \mathrm{M}$ (excluding the $\mathrm{Ce}\left(\mathrm{SO}_{4}\right)_{2} \cdot 5 \mathrm{H}_{2} \mathrm{O}$ species from Figure 5).

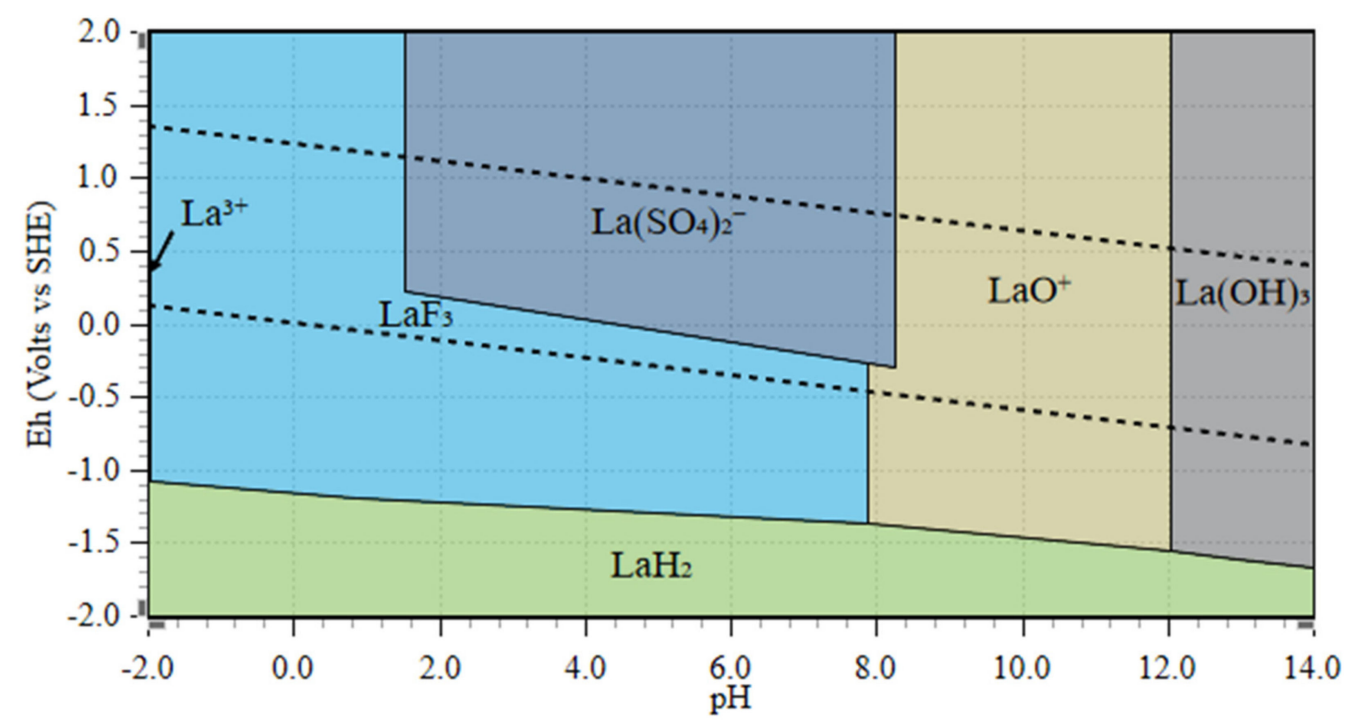

Figure 7. Eh-pH diagram of the La-F-SO $\mathrm{SO}_{4}-\mathrm{H}_{2} \mathrm{O}$ system for bastnaesite leaching in $\mathrm{H}_{2} \mathrm{SO}_{4}$ at $25{ }^{\circ} \mathrm{C}$ : $\mathrm{La}=10^{-3} \mathrm{M}, \mathrm{F}=10^{-3} \mathrm{M}, \mathrm{S}=1.0 \mathrm{M}$.

\subsubsection{Monazite Leaching}

The leaching of monazite using $1 \mathrm{M} \mathrm{H}_{2} \mathrm{SO}_{4}, 1 \mathrm{M} \mathrm{HCl}$ and $1 \mathrm{M} \mathrm{HNO}_{3}$ resulted in $\mathrm{Ce}$ recovery values of $0.5,0.7$ and $0.7 \%$, respectively (Figure 1 ). The results indicate the poor leachability of monazite under the designed leaching conditions. To further investigate the leaching reaction of $\mathrm{Ce}$ in monazite, $\mathrm{Eh}-\mathrm{pH}$ diagrams of monazite solubility in $\mathrm{HCl}$ and $\mathrm{HNO}_{3}$ systems were developed as shown in Figures 8-15, respectively.

In the $\mathrm{HCl}$ leaching system, $\mathrm{Ce}$ is leached into the solution in its trivalent state and subsequently forms a soluble complex with $\mathrm{Cl}^{-}$in the solution as indicated by the gray region of $\mathrm{Ce}^{3+}$ in Figure 8 [13]. A similar result occurs in the $\mathrm{HNO}_{3}$ leaching system, wherein Ce mainly exists in its trivalent state at $\mathrm{pH}$ values lower than 3.5, either as a free ion or complexed with $\mathrm{NO}_{3}{ }^{-}$. From $\mathrm{pH} 3.5$ to 11, the main species of Ce are phosphate and oxide compounds, which are insoluble forms. The precipitation of Ce hydroxide occurs at $\mathrm{pH}$ values higher than 11 . 
According to the Eh-pH diagrams, the leachability of $\mathrm{Ce}$ is comparatively higher under low $\mathrm{pH}$ conditions $(\mathrm{pH}<3.5)$. Under these conditions, $\mathrm{Ce}$ is in an ionic trivalent form across the water stability region. However, experimental data indicates that the leaching recovery of $\mathrm{Ce}$ is less than $1 \%$ in $1 \mathrm{M} \mathrm{H}_{2} \mathrm{SO}_{4}, 1 \mathrm{M} \mathrm{HCl}$ and $1 \mathrm{M} \mathrm{HNO}_{3}$ solutions (Figure 1 ). This result is likely due to the occurrence of $\mathrm{Ce}$ in the feed material in a crystalline state, which requires more energy for Ce to be leached from the associated minerals [27]. As previously reported, a possible reason for low monazite leaching is the difficulty to chemically decompose the mineral structure of monazite and dissolve the REEs into solution [28-30]. As shown in Figure 9 through Figures 11, 13 and 14, La and $\mathrm{Nd}$ are not soluble except under very acidic conditions. As such, only surface amounts of Ce may be solubilized and leaching diminishes due to the impenetrability ( $\mathrm{Nd}$ and La insoluble compounds) into the mineral particle. Furthermore, any leaching results in the formation of insoluble complexes in the leaching solution, such as $\mathrm{CePO}_{4}, \mathrm{LaPO}_{4}$ and $\mathrm{NdPO}_{4}$, which accumulates on the mineral surfaces, thereby preventing a further reaction between the minerals and leaching agents, and consequently resulting in low recovery values. Therefore, more aggressive leaching conditions, such as a higher temperature or stronger acidity, may favor the leaching process.

The Eh-pH diagrams of Th shown in Figures 11 and 15 indicate that, in both the $\mathrm{HCl}$ and $\mathrm{HNO}_{3}$ systems, Th has a wider stability region from $\mathrm{pH}-2$ to 8 due to its ionic forms, i.e., $\mathrm{ThH}_{3} \mathrm{PO}_{4}{ }^{4+}$ and $\mathrm{Th}\left(\mathrm{HPO}_{4}\right)_{3}{ }^{2-}$. This result indicates that Th will likely stay in the solution after being leached rather than precipitating as a solid.

Unlike other rare earth elements, which are only stable in their trivalent state $\left(\mathrm{REE}^{3+}\right)$, Ce commonly exists in trivalent $\left(\mathrm{Ce}^{3+}\right)$ and tetravalent states $\left(\mathrm{Ce}^{4+}\right)$ in solution. Tetravalent $\mathrm{Ce}\left(\mathrm{Ce}^{4+}\right)$ is more stable than its trivalent state $\left(\mathrm{Ce}^{3+}\right)$. Insoluble complexes formed by $\mathrm{Ce}^{4+}$ and phosphate (i.e., $\mathrm{CePO}_{4}$ ) show a higher stability than their sulphate or hydroxide forms [31]. The Eh-pH diagrams of Ce species in the $\mathrm{Cl}^{-}$and $\mathrm{NO}_{3}{ }^{-}$systems indicate that Ce cannot exist in solutions as its ionic tetravalent form $\left(\mathrm{Ce}^{4+}\right)$. Instead, it either exists as $\mathrm{Ce}^{3+}$ or forms complexes as $\mathrm{CeClO}_{4}{ }^{2+}$ and $\mathrm{CeNO}_{3}{ }^{2+}$ in the presence of $\mathrm{Cl}^{-}$and $\mathrm{NO}_{3}{ }^{-}$, respectively, as indicated by Figures 8 and 12. In other words, if $\mathrm{Ce}$ is pre-oxidized to $\mathrm{Ce}^{4+}$, it will not be easily leached into solution and the separation between $\mathrm{Ce}^{4+}$ and other $\mathrm{REE}^{3+}$ species can therefore be achieved.

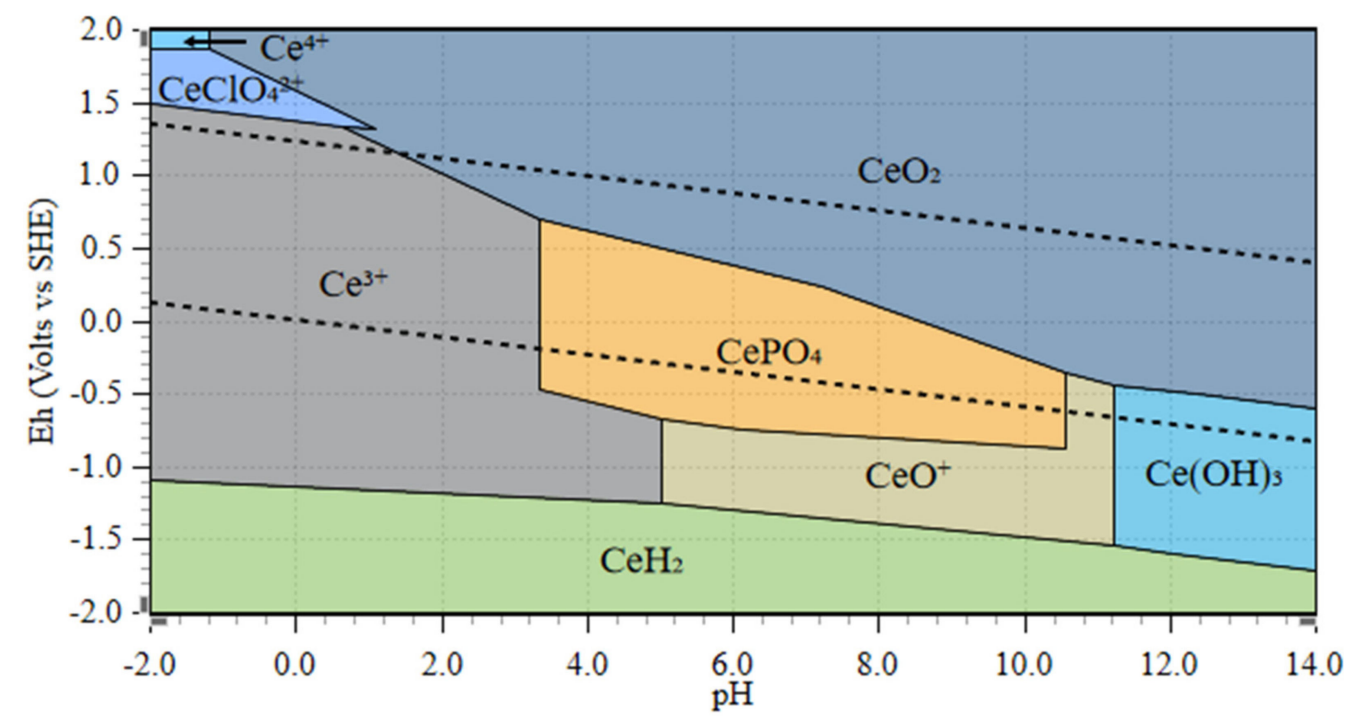

Figure 8. Eh-pH diagram of the $\mathrm{Ce}-\mathrm{PO}_{4}-\mathrm{Cl}-\mathrm{H}_{2} \mathrm{O}$ system for monazite leaching in $\mathrm{HCl}$ at $25{ }^{\circ} \mathrm{C}$ : $\mathrm{Ce}=10^{-3} \mathrm{M}, \mathrm{P}=10^{-3} \mathrm{M}, \mathrm{Cl}=1.0 \mathrm{M}$. 


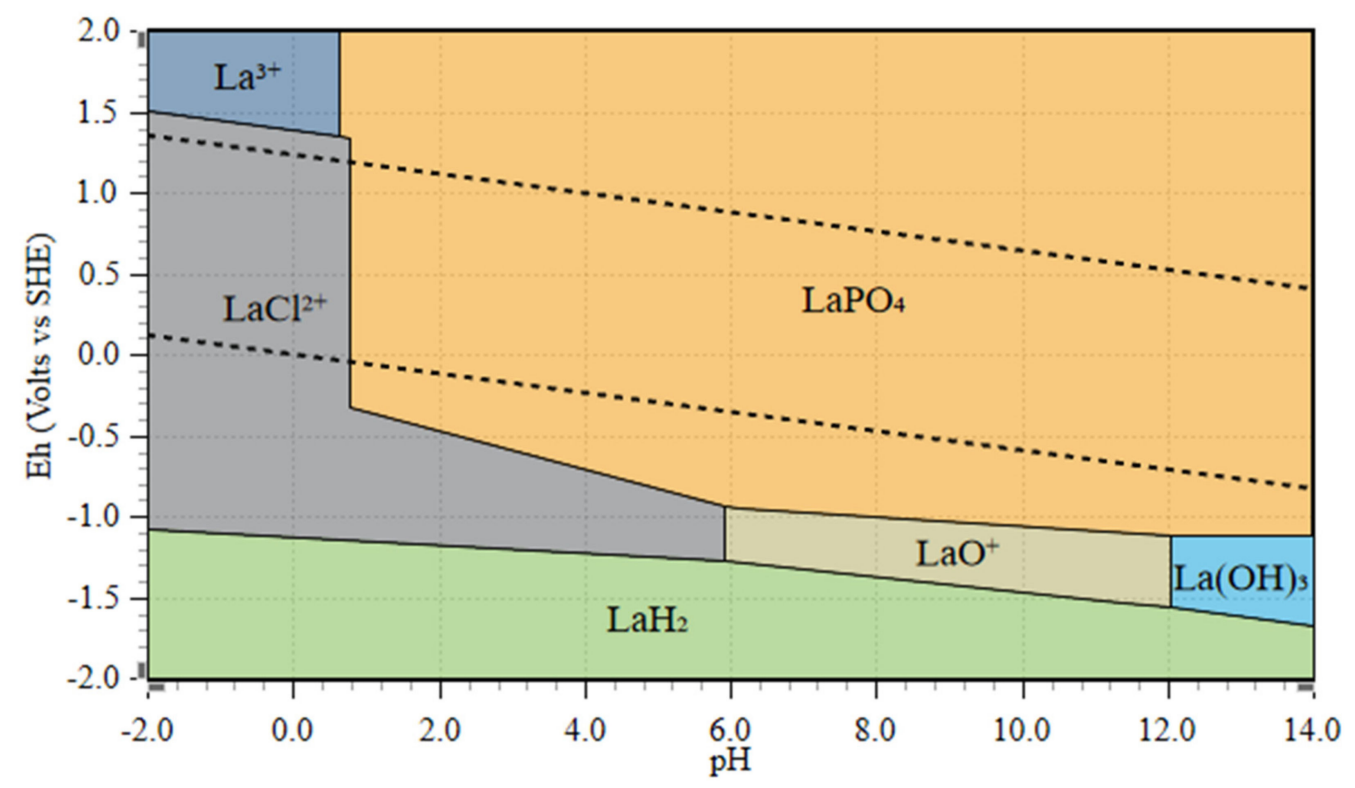

Figure 9. Eh-pH diagram of the $\mathrm{La}-\mathrm{PO}_{4}-\mathrm{Cl}-\mathrm{H}_{2} \mathrm{O}$ system for monazite leaching in $\mathrm{HCl}$ at $25{ }^{\circ} \mathrm{C}$ : $\mathrm{La}=10^{-3} \mathrm{M}, \mathrm{P}=10^{-3} \mathrm{M}, \mathrm{Cl}=1.0 \mathrm{M}$.

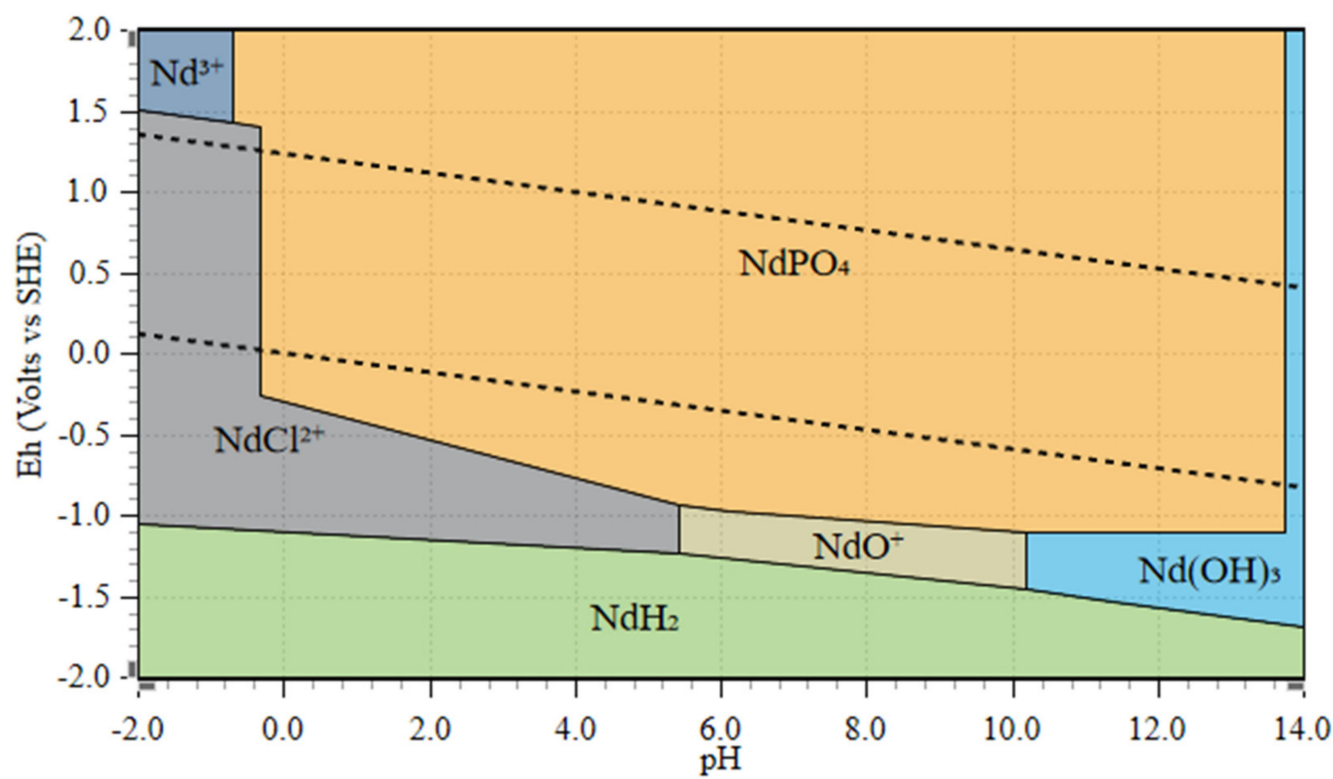

Figure 10. Eh-pH diagram of the $\mathrm{Nd}-\mathrm{PO}_{4}-\mathrm{Cl}-\mathrm{H}_{2} \mathrm{O}$ system for monazite leaching in $\mathrm{HCl}$ at $25{ }^{\circ} \mathrm{C}$ : $\mathrm{Nd}=10^{-3} \mathrm{M}, \mathrm{P}=10^{-3} \mathrm{M}, \mathrm{Cl}=1.0 \mathrm{M}$. 


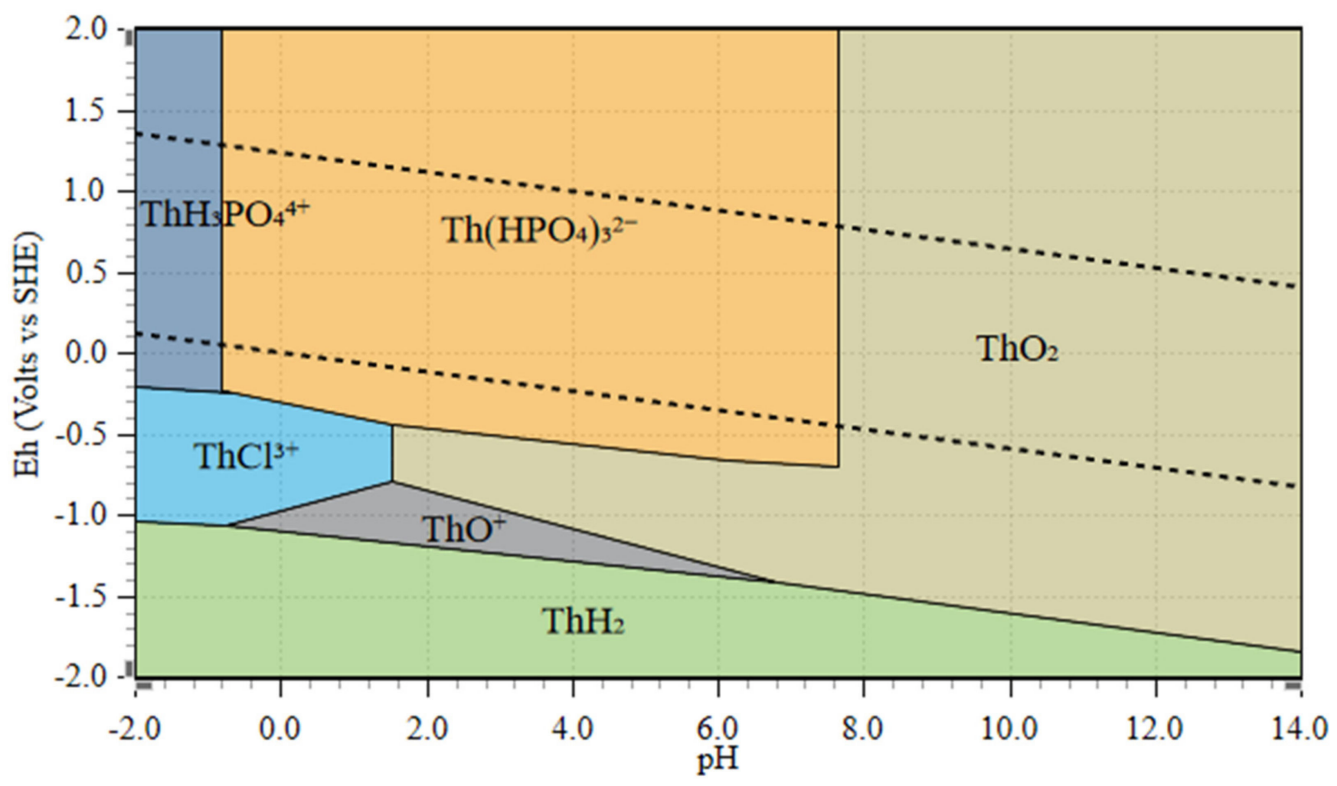

Figure 11. Eh-pH diagram of the Th- $\mathrm{PO}_{4}-\mathrm{Cl}-\mathrm{H}_{2} \mathrm{O}$ system for monazite leaching in $\mathrm{HCl}$ at $25^{\circ} \mathrm{C}$ : $\mathrm{Th}=10^{-3} \mathrm{M}, \mathrm{P}=10^{-3} \mathrm{M}, \mathrm{Cl}=1.0 \mathrm{M}$.

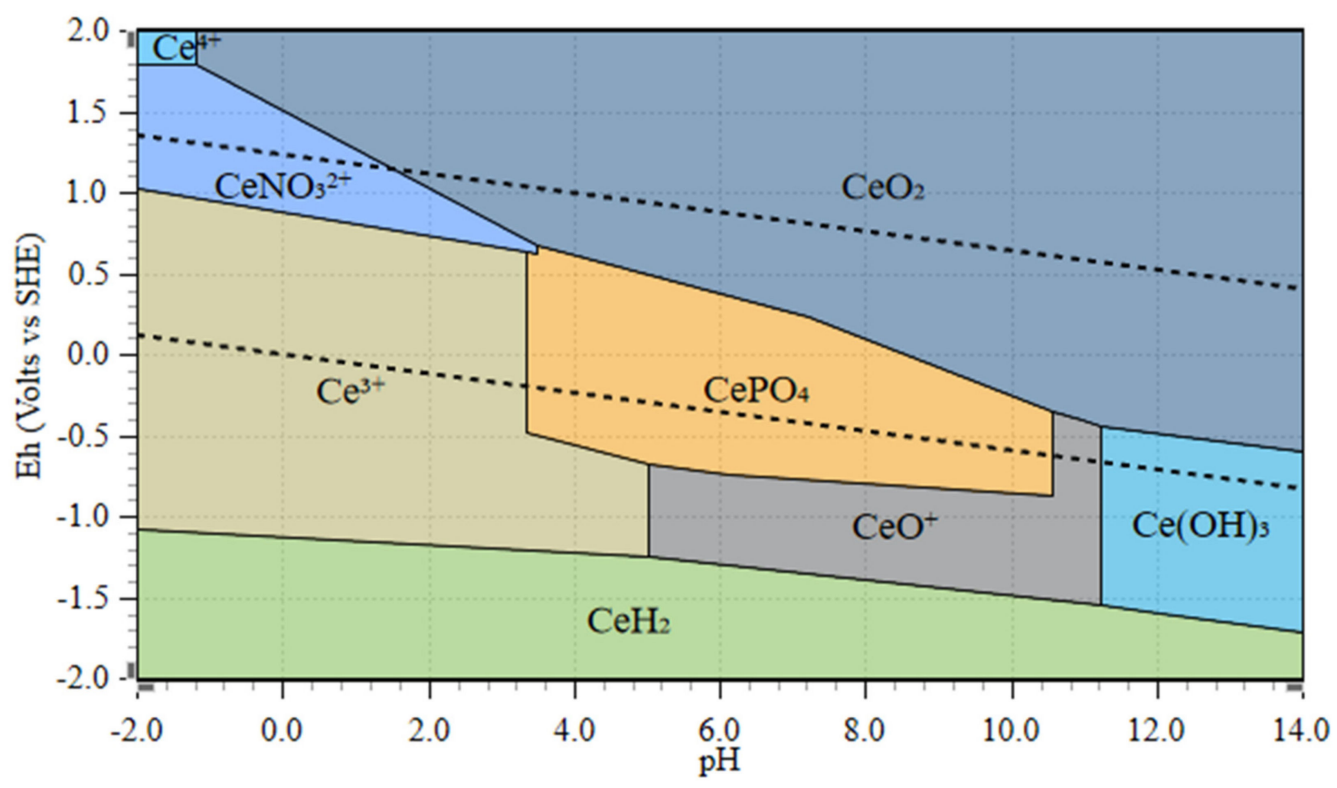

Figure 12. Eh-pH diagram of the $\mathrm{Ce}-\mathrm{PO}_{4}-\mathrm{NO}_{3}-\mathrm{H}_{2} \mathrm{O}$ system for monazite leaching in $\mathrm{HNO}_{3}$ at $25^{\circ} \mathrm{C}$ : $\mathrm{Ce}=10^{-3} \mathrm{M}, \mathrm{P}=10^{-3} \mathrm{M}, \mathrm{N}=1.0 \mathrm{M}$. 


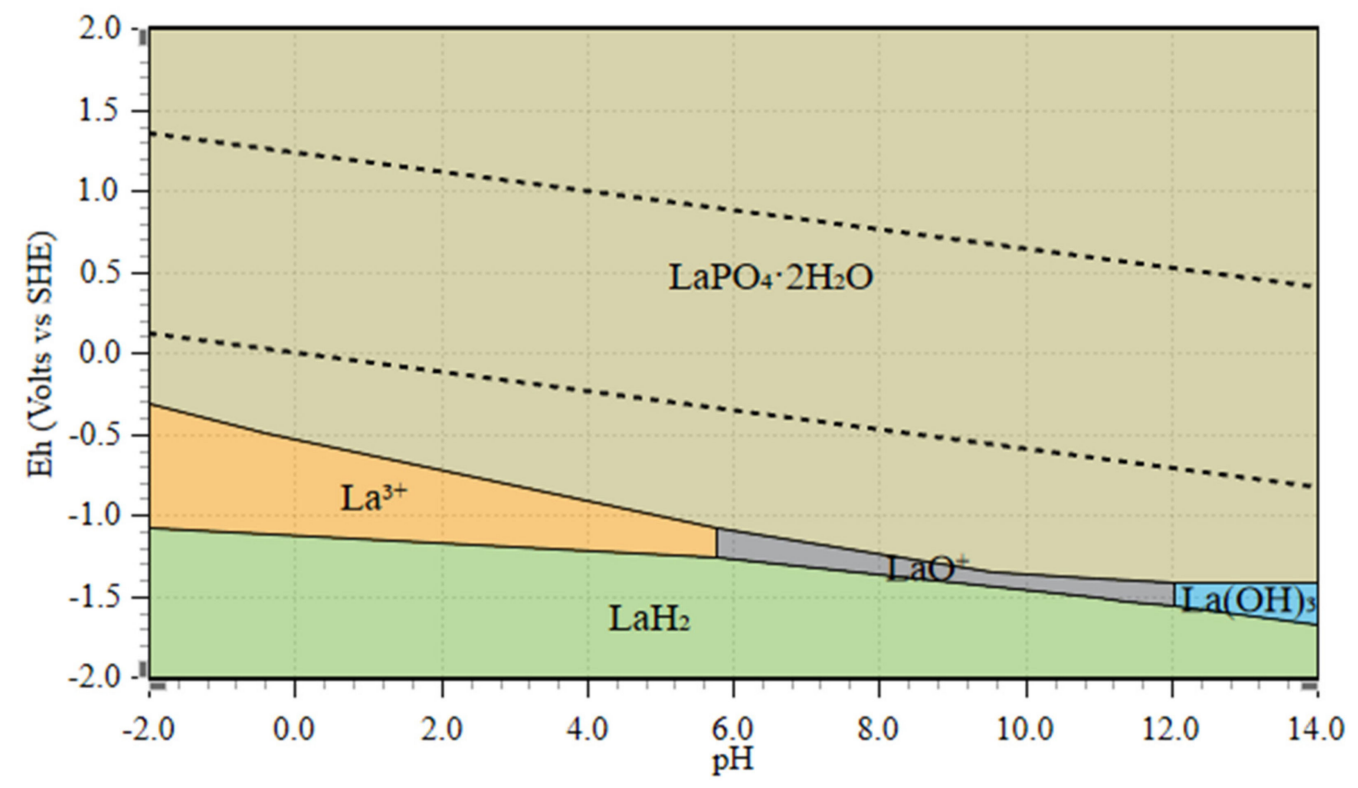

Figure 13. Eh-pH diagram of the $\mathrm{La}-\mathrm{PO}_{4}-\mathrm{NO}_{3}-\mathrm{H}_{2} \mathrm{O}$ system for monazite leaching in $\mathrm{HNO}_{3}$ at $25^{\circ} \mathrm{C}$ : $\mathrm{La}=10^{-3} \mathrm{M}, \mathrm{P}=10^{-3} \mathrm{M}, \mathrm{N}=1.0 \mathrm{M}$.

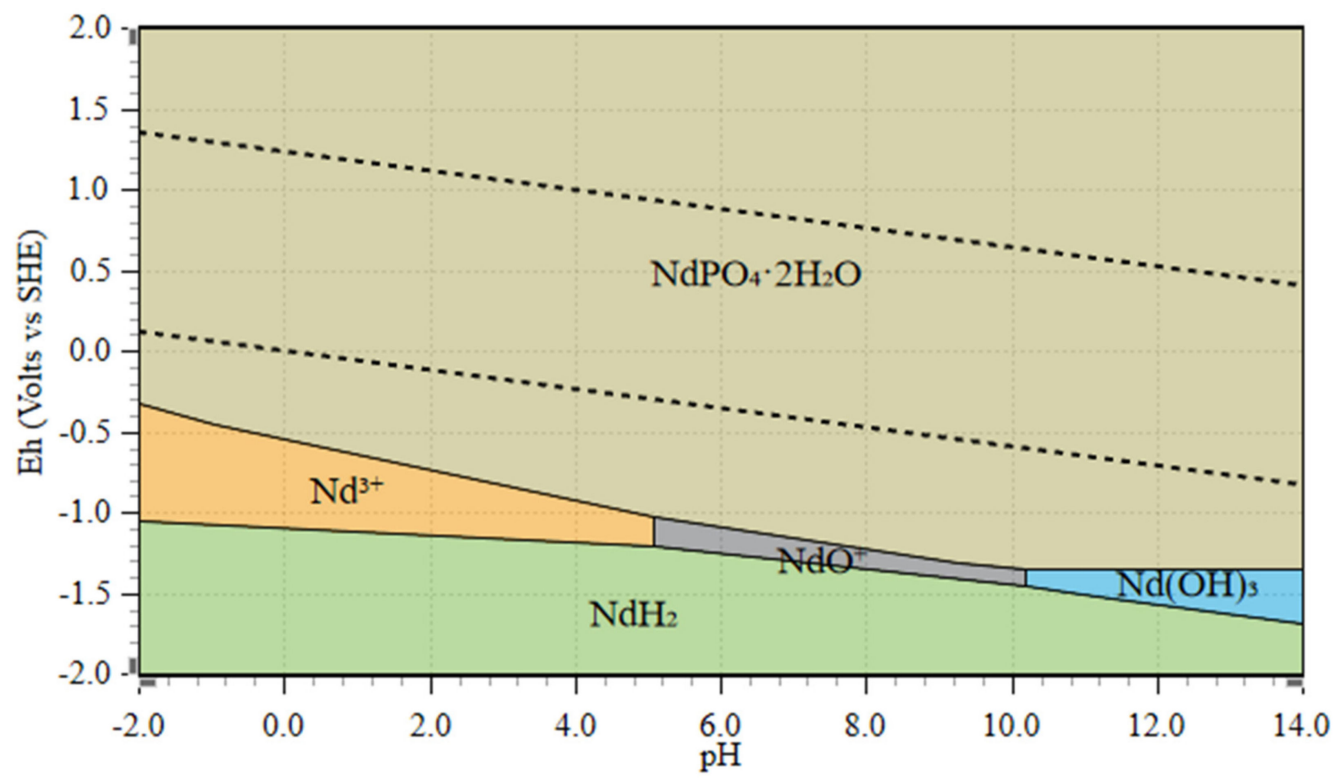

Figure 14. Eh-pH diagram of the $\mathrm{Nd}-\mathrm{PO}_{4}-\mathrm{NO}_{3}-\mathrm{H}_{2} \mathrm{O}$ system for monazite leaching in $\mathrm{HNO}_{3}$ at $25^{\circ} \mathrm{C}$ : $\mathrm{Nd}=10^{-3} \mathrm{M}, \mathrm{P}=10^{-3} \mathrm{M}, \mathrm{N}=1.0 \mathrm{M}$. 


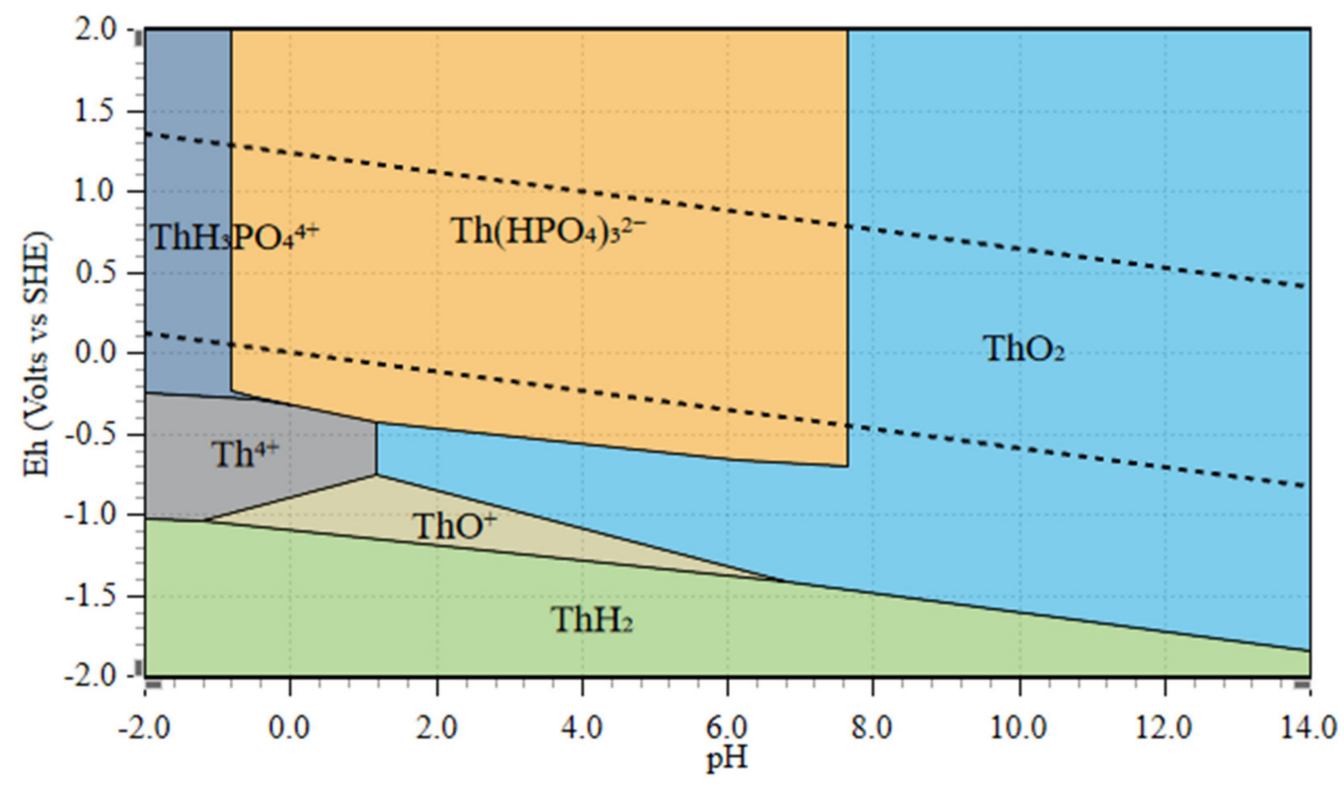

Figure 15. Eh-pH diagram of the Th- $\mathrm{PO}_{4}-\mathrm{NO}_{3}-\mathrm{H}_{2} \mathrm{O}$ system for monazite leaching in $\mathrm{HNO}_{3}$ at $25^{\circ} \mathrm{C}$ : $\mathrm{Th}=10^{-3} \mathrm{M}, \mathrm{P}=10^{-3} \mathrm{M}, \mathrm{N}=1.0 \mathrm{M}$.

\subsubsection{Xenotime Leaching}

The Eh-pH diagrams for xenotime leaching in the $\mathrm{H}_{2} \mathrm{SO}_{4}, \mathrm{HCl}$ and $\mathrm{HNO}_{3}$ systems are shown in Figures 16-18. The gray region in all three charts represent the ionic region of $\mathrm{Y}^{3+}$ (in the $\mathrm{Y}-\mathrm{PO}_{4}-\mathrm{SO}_{4}$ and $\mathrm{Y}-\mathrm{PO}_{4}-\mathrm{NO}_{3}$ systems) and $\mathrm{YCl}^{2+}$ (in the $\mathrm{Y}-\mathrm{PO}_{4}-\mathrm{Cl}$ system), respectively. The wide regions of yttrium phosphate overlapping with the water stability region (within the two dash lines) indicate that the leaching of xenotime in $\mathrm{H}_{2} \mathrm{SO}_{4}, \mathrm{HCl}$ and $\mathrm{HNO}_{3}$ was limited by the formation of a phosphate precipitant. The recovery of $\mathrm{Y}$ in xenotime was 17,8 and $11 \%$ using $1 \mathrm{M} \mathrm{H}_{2} \mathrm{SO}_{4}, 1 \mathrm{M} \mathrm{HCl}$ and $1 \mathrm{M} \mathrm{HNO}_{3}$, respectively. In sulfate systems, the formation of ionic species $\mathrm{YSO}_{4}{ }^{+}$at $\mathrm{pH}$ values from 0 to 0.5 indicates higher leachability of xenotime in sulfuric acid. This correlates well with our experimental data where the highest recovery occurs when using sulfuric acid is used as the lixiviant (Figure 4).

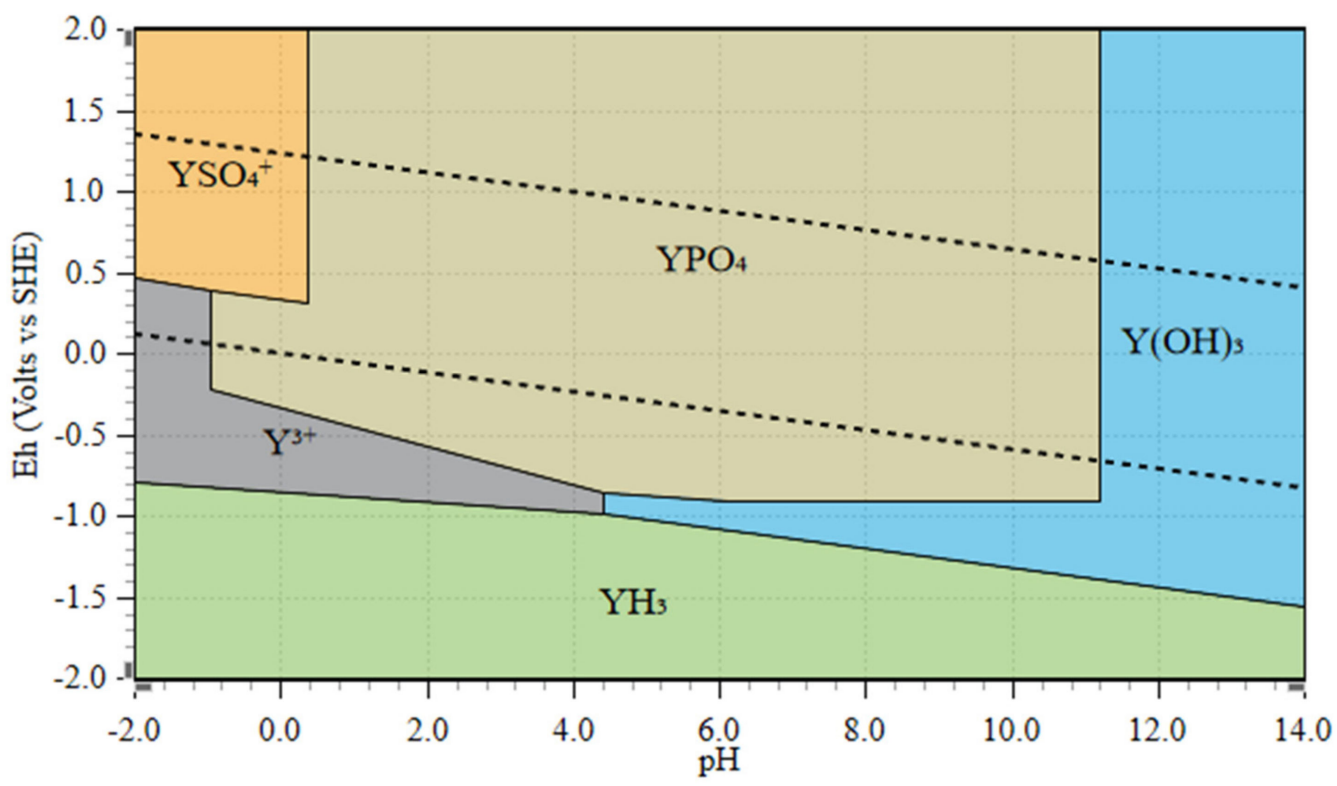

Figure 16. Eh- $\mathrm{pH}$ diagram of the $\mathrm{Y}-\mathrm{PO}_{4}-\mathrm{SO}_{4}-\mathrm{H}_{2} \mathrm{O}$ system for xenotime leaching in $\mathrm{H}_{2} \mathrm{SO}_{4}$ at $25{ }^{\circ} \mathrm{C}$ : $\mathrm{Y}=10^{-3} \mathrm{M}, \mathrm{P}=10^{-3} \mathrm{M}, \mathrm{S}=1.0 \mathrm{M}$. 


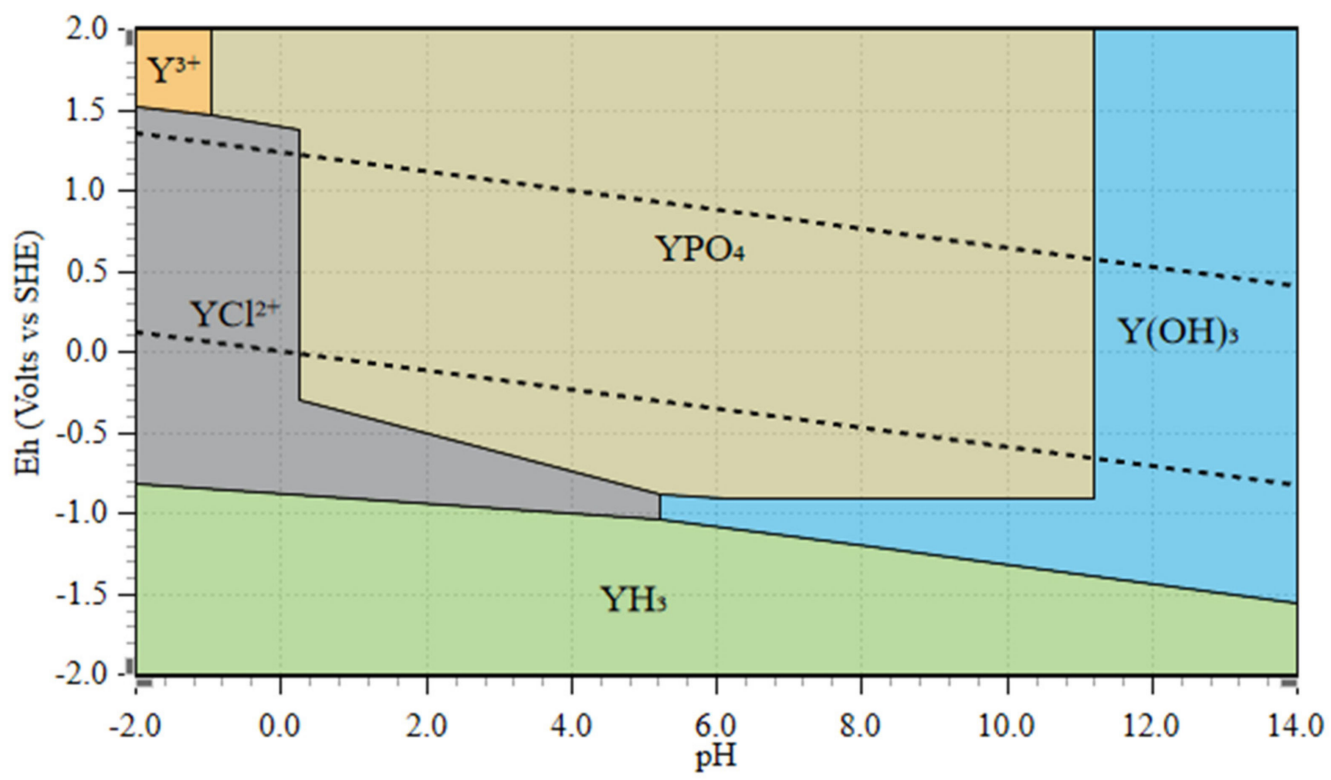

Figure 17. Eh-pH diagram of the $\mathrm{Y}_{-} \mathrm{PO}_{4}-\mathrm{Cl}-\mathrm{H}_{2} \mathrm{O}$ system for xenotime leaching in $\mathrm{HCl}$ at $25^{\circ} \mathrm{C}$ : $\mathrm{Y}=10^{-3} \mathrm{M}, \mathrm{P}=10^{-3} \mathrm{M}, \mathrm{Cl}=1.0 \mathrm{M}$.

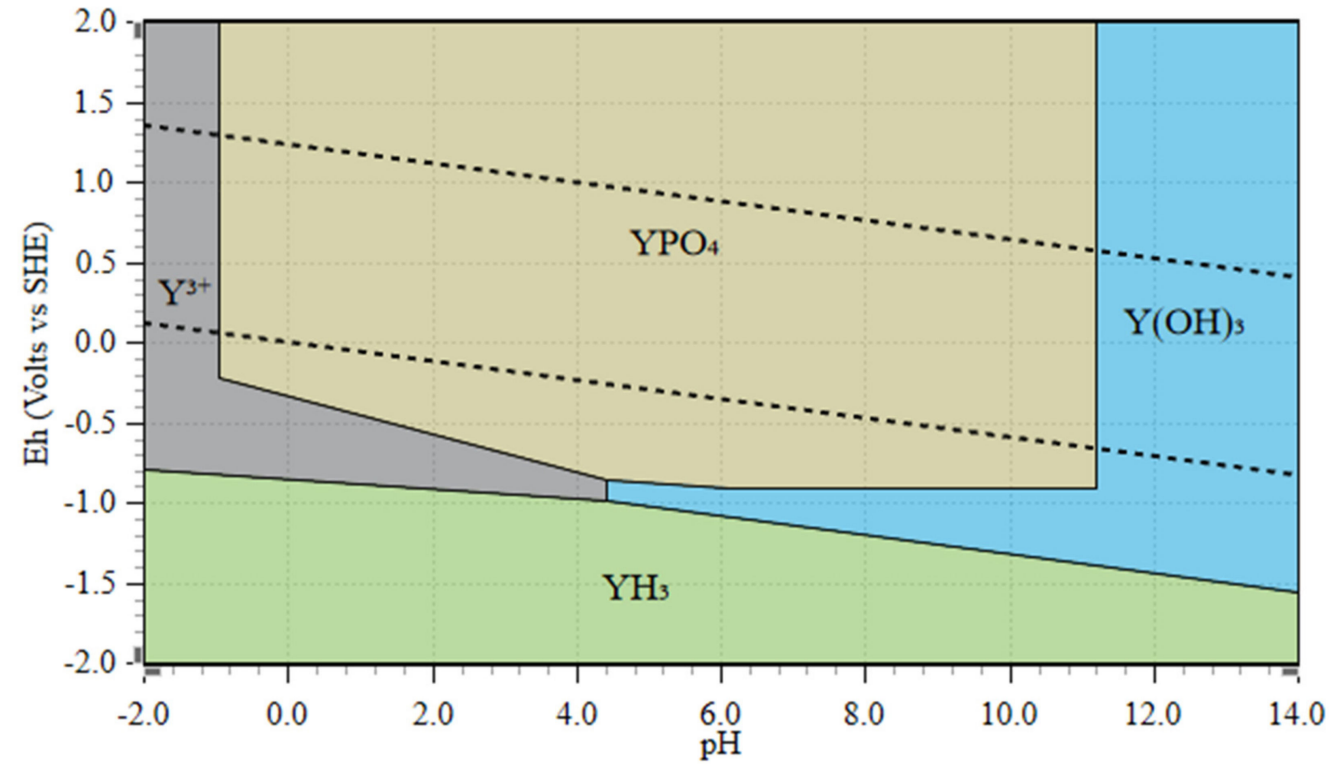

Figure 18. Eh-pH diagram for the $\mathrm{Y}-\mathrm{PO}_{4}-\mathrm{NO}_{3}-\mathrm{H}_{2} \mathrm{O}$ system for xenotime leaching in $\mathrm{HNO}_{3}$ at $25^{\circ} \mathrm{C}$ : $\mathrm{Y}=10^{-3} \mathrm{M}, \mathrm{P}=10^{-3} \mathrm{M}, \mathrm{N}=1.0 \mathrm{M}$.

\subsection{Eh-pH Diagrams of the Main Contaminants}

Commonly associated contaminants in REE systems include iron, calcium and aluminum. The Eh-pH diagrams showed some solubility of $\mathrm{REE}^{3+} / \mathrm{Ce}^{3+}$ in low $\mathrm{pH}$ regions. However, the actual leach recovery values were lower than anticipated. A possible explanation is the formation of a product or precipitation layer on the surface of the minerals by contaminants. The product layer may block the mineral surface, thereby inhibiting the reaction between the acids and the minerals. Similar phenomena have been reported by other researchers [15,31,32]. To further understand the impact of contaminants on leaching, Eh-pH diagrams (Figures 19-22) of the three major contaminating elements, i.e., $\mathrm{Fe}, \mathrm{Ca}$ and $\mathrm{Al}$, were generated for the $1 \mathrm{M} \mathrm{H}_{2} \mathrm{SO}_{4}, 1 \mathrm{M} \mathrm{HCl}$ and $1 \mathrm{M} \mathrm{HNO}_{3}$ systems, respectively. In the 
three acid leaching systems, Fe shows the ability to form different species of precipitants, which may be the main factor that causes the passivation effect on the mineral surfaces.

The Eh-pH diagram of $\mathrm{Fe}, \mathrm{Ca}$ and $\mathrm{Al}$ in the sulfuric acid leaching system (Figure 19) shows the presence of goethite $(\mathrm{FeO} \cdot \mathrm{OH})$, hydrated rhomboclase $\left(\mathrm{H}_{3} \mathrm{OFe}\left(\mathrm{SO}_{4}\right)_{2} \cdot 3 \mathrm{H}_{2} \mathrm{O}\right)$ and calcium ferrite $\left(\mathrm{CaO} \cdot \mathrm{Fe}_{2} \mathrm{O}_{3}\right)$, under corresponding leaching conditions. However, the stability region of $\mathrm{H}_{3} \mathrm{OFe}\left(\mathrm{SO}_{4}\right)_{2} \cdot 3 \mathrm{H}_{2} \mathrm{O}$ and $\mathrm{Fe}\left(\mathrm{SO}_{4}\right)_{3} \cdot 5.03 \mathrm{H}_{2} \mathrm{O}$ overshadowed the stability region of $\mathrm{Fe}^{3+}$ and $\mathrm{FeO} \cdot \mathrm{OH}$ across the water stability region (from $\mathrm{pH}-2$ to 12 ). The stable occurrence of $\mathrm{H}_{3} \mathrm{OFe}\left(\mathrm{SO}_{4}\right)_{2} \cdot 3 \mathrm{H}_{2} \mathrm{O}$ and $\mathrm{Fe}\left(\mathrm{SO}_{4}\right)_{3} \cdot 5.03 \mathrm{H}_{2} \mathrm{O}$ contradicts the fact that $\mathrm{Fe}^{3+}$ and $\mathrm{FeO} \cdot \mathrm{OH}$ should be the dominant Fe species in the sulfate system. Moreover, $\left(\mathrm{H}_{3} \mathrm{OFe}\left(\mathrm{SO}_{4}\right)_{2} \cdot 3 \mathrm{H}_{2} \mathrm{O}\right.$ and $\left.\mathrm{Fe}\left(\mathrm{SO}_{4}\right)_{3} \cdot 5.03 \mathrm{H}_{2} \mathrm{O}\right)$ may form at time scales beyond those of typical leaching due to slow kinetics. Therefore, the Eh- $\mathrm{pH}$ diagram for the Fe-Ca-Al$\mathrm{NO}_{3}-\mathrm{H}_{2} \mathrm{O}$ system was modified by omitting $\mathrm{H}_{3} \mathrm{OFe}\left(\mathrm{SO}_{4}\right)_{2} \cdot 3 \mathrm{H}_{2} \mathrm{O}$ and $\mathrm{Fe}\left(\mathrm{SO}_{4}\right)_{3} \cdot 5.03 \mathrm{H}_{2} \mathrm{O}$, while keeping all other conditions the same. As shown in the modified Eh-pH diagram (Figure 20), the dominant Fe species under $\mathrm{pH} 1$ is either $\mathrm{Fe}^{3+}$ (at Eh above $0.65 \mathrm{~V}$ vs. SHE) or $\mathrm{Fe}^{2+}$ (at Eh below $0.65 \mathrm{~V}$ vs. SHE). As pH and Eh increase, $\mathrm{FeO} \cdot \mathrm{OH}$ starts to form and dominates the stability region in the sulfate system. The Eh-pH diagram for the Fe-S- $\mathrm{H}_{2} \mathrm{O}$ system at $298 \mathrm{~K}$ reported by Bernardez et al. also corroborates our findings [33].

In the modified Eh-pH diagram (Figure 20), goethite (FeO-OH) is considered the main product that could cause passivation on the mineral surface. The formation of $\mathrm{FeO} \cdot \mathrm{OH}$ can be described as:

$$
\mathrm{Fe}_{2}\left(\mathrm{SO}_{4}\right)_{3}+4 \mathrm{H}_{2} \mathrm{O} \rightarrow 2 \mathrm{FeOOH}+3 \mathrm{H}_{2} \mathrm{SO}_{4}
$$

For REE leaching, the formation of $\mathrm{FeO} \cdot \mathrm{OH}, \mathrm{Fe}_{3} \mathrm{O}_{4}$ and $\mathrm{CaO} \cdot \mathrm{Fe}_{2} \mathrm{O}_{3}$ (as shown in Figure 20) can inhibit the leaching process by preventing contact between the mineral surfaces and the leaching agent in solution.

In $\mathrm{HCl}$ leaching systems, Fe mainly exists at a +3 state at $\mathrm{pH}$ values lower than 6.0 and starts to form a FeO.OH precipitate at $\mathrm{pH}$ values above 6.0, as shown in Figure 21. In $\mathrm{HNO}_{3}$ systems, $\mathrm{Fe}$ exists as either $\mathrm{Fe}^{2+}$ or $\mathrm{Fe}^{3+}$ below $\mathrm{pH}$ 1.0, as shown in Figure 22. Generally, Fe exists in its ionic forms at low $\mathrm{pH}$ and low Eh conditions, which indicates that the leaching of RE minerals containing Fe may be more favorable under these conditions.

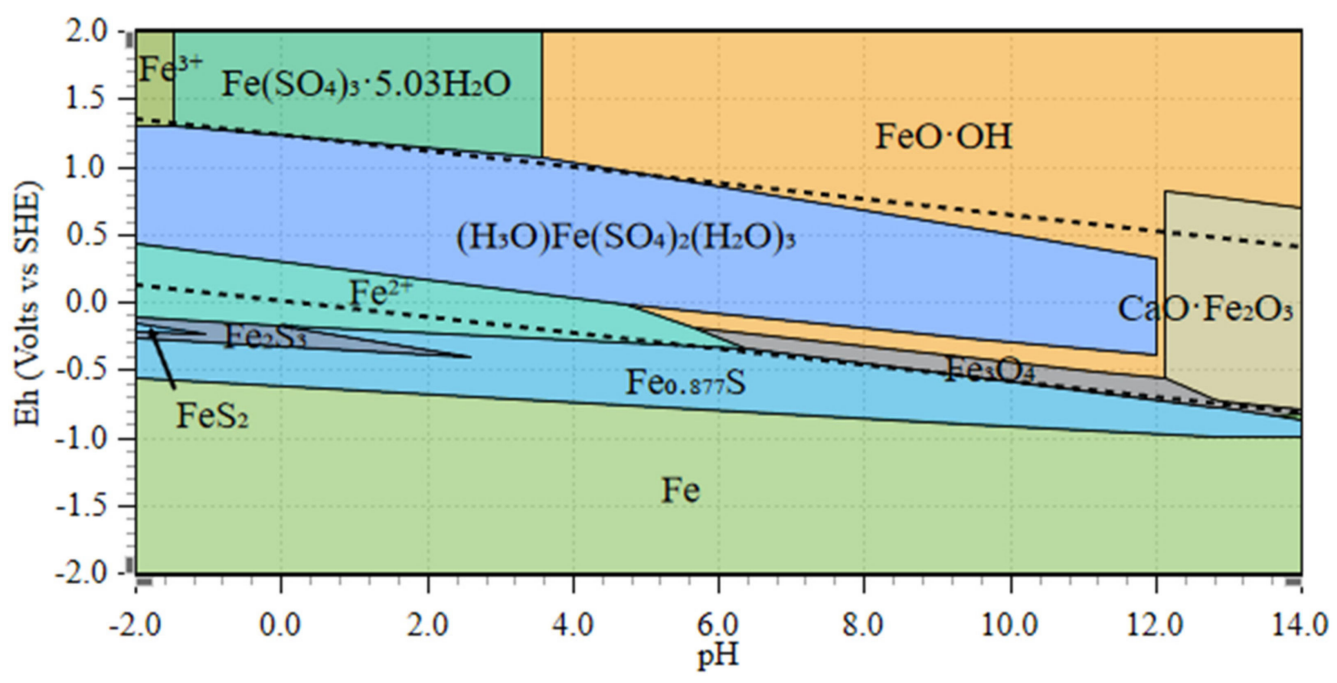

Figure 19. Eh-pH diagram for the Fe-Ca-Al- $\mathrm{SO}_{4}-\mathrm{H}_{2} \mathrm{O}$ system at $25^{\circ} \mathrm{C}: \mathrm{Fe}=10^{-3} \mathrm{M}, \mathrm{Ca}=10^{-3} \mathrm{M}$, $\mathrm{Al}=10^{-3} \mathrm{M}, \mathrm{S}=1.0 \mathrm{M}$. 


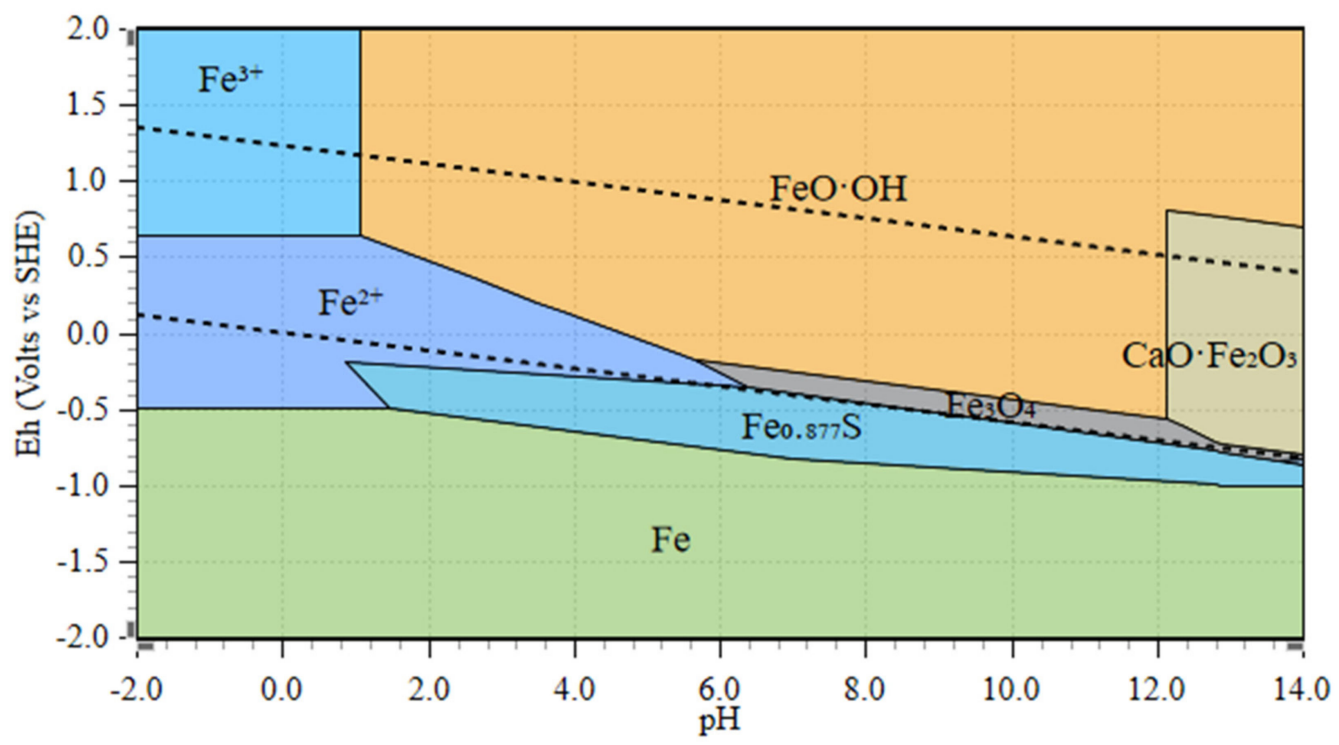

Figure 20. Modified Eh-pH diagram for the Fe-Ca-Al- $\mathrm{SO}_{4}-\mathrm{H}_{2} \mathrm{O}$ system at $25{ }^{\circ} \mathrm{C}: \mathrm{Fe}=10^{-3} \mathrm{M}$, $\mathrm{Ca}=10^{-3} \mathrm{M}, \mathrm{Al}=10^{-3} \mathrm{M}, \mathrm{N}=1.0 \mathrm{M}$ (excluding the $\mathrm{H}_{3} \mathrm{OFe}\left(\mathrm{SO}_{4}\right)_{2} \cdot 3 \mathrm{H}_{2} \mathrm{O}$ and $\mathrm{Fe}\left(\mathrm{SO}_{4}\right)_{3} \cdot 5.03 \mathrm{H}_{2} \mathrm{O}$ from Figure 19).

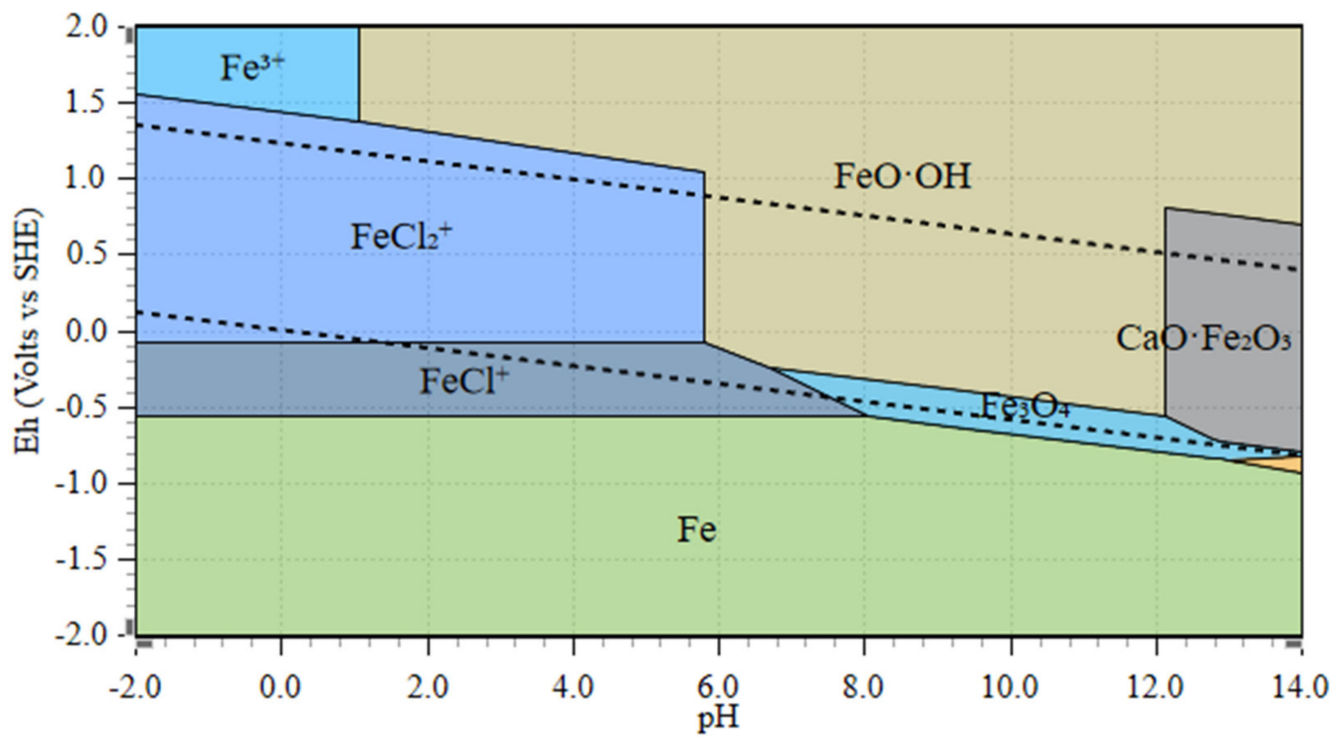

Figure 21. Eh-pH diagram for the $\mathrm{Fe}-\mathrm{Ca}-\mathrm{Al}-\mathrm{Cl}-\mathrm{H}_{2} \mathrm{O}$ system at $25^{\circ} \mathrm{C}: \mathrm{Fe}=10^{-3} \mathrm{M}, \mathrm{Ca}=10^{-3} \mathrm{M}$, $\mathrm{Al}=10^{-3} \mathrm{M}, \mathrm{Cl}=1.0 \mathrm{M}$. 


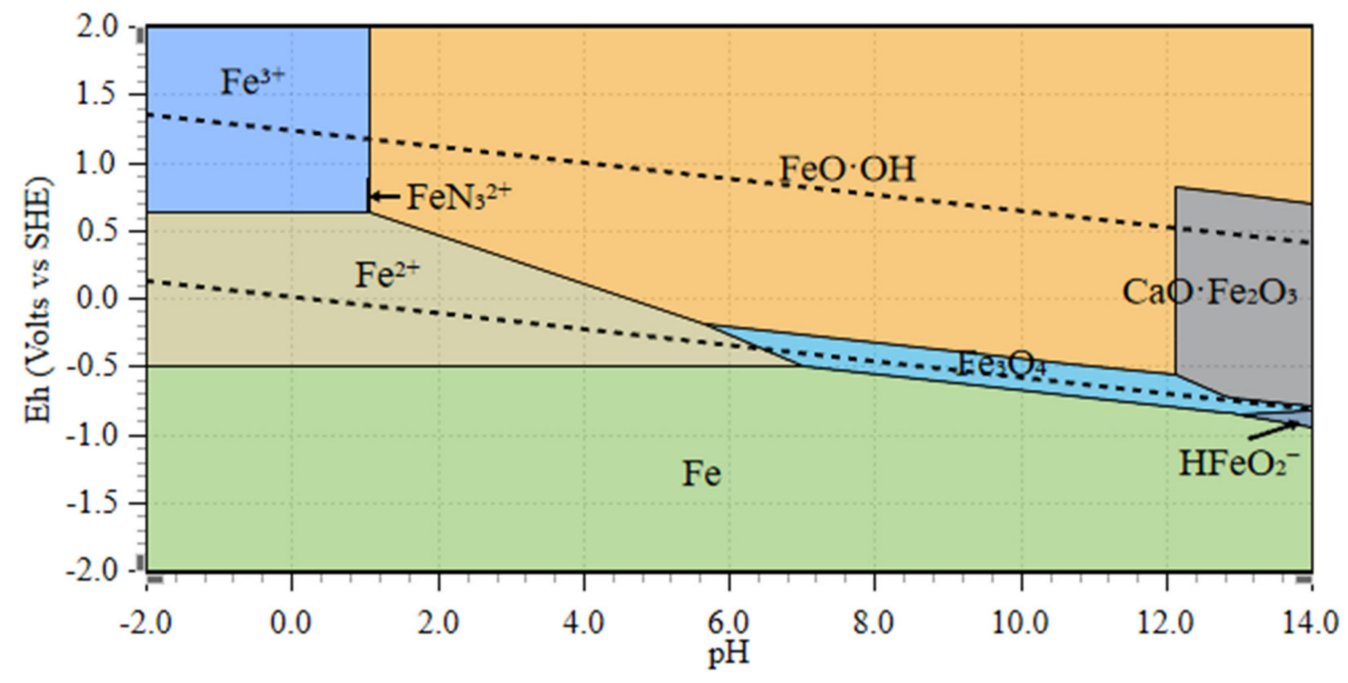

Figure 22. Eh-pH diagram for the Fe-Ca-Al- $\mathrm{NO}_{3}-\mathrm{H}_{2} \mathrm{O}$ system at $25^{\circ} \mathrm{C}$ : $\mathrm{Fe}=10^{-3} \mathrm{M}, \mathrm{Ca}=10^{-3} \mathrm{M}$, $\mathrm{Al}=10^{-3} \mathrm{M}, \mathrm{N}=1.0 \mathrm{M}$.

\section{Thermodynamic Data from the HSC Database and Other Sources}

The data used in generating the Eh-pH diagrams are listed in Table 1 (see Appendix A). The various Gibbs free energies are listed because there are different values of the same species reported in other resources due to the difference in crystallinity. The species with multiple values reported are indicated in Table 1. It is noted that the Gibbs free energy for $\mathrm{ThH}_{2} \mathrm{PO}_{4}{ }^{2+}$ varies from -434.174 to $-723.550 \mathrm{kcal} / \mathrm{mol}$ in the HSC 9.9 and the HSC 5.11 databases, respectively, which causes differences in the corresponding Eh-pH diagrams. In addition, new species that are not included in the HSC 9.9 database but are reported in other publications are also included in Table 1 (see Appendix A). For example, the Gibbs free energy for an insoluble cerium sulphate, $\mathrm{Ce}_{2}\left(\mathrm{SO}_{4}\right)_{3} \cdot 8 \mathrm{H}_{2} \mathrm{O}$, is excluded in the HSC database but reported in other studies by Dean and Wagman $[34,35]$. The importance of having all the available thermodynamic data of the requisite species is that the effect of different thermodynamic data and the presence of different species on the Eh-pH diagrams can be determined. Future work will be focused on importing the missing species and updating the thermodynamic data to see how the Eh-pH diagrams change accordingly. The comparison between Eh-pH diagrams resulting from different thermodynamic data will also help to gain a better understanding of how species with different crystallinities behave chemically in solution.

\section{Conclusions}

In this work, a literature review was performed relating to the Eh-pH diagrams of three RE minerals, i.e., bastnaesite, monazite and xenotime, in aqueous systems. Eh-pH diagrams of RE minerals in hydrometallurgical systems that were not previously reported in the literature were developed in this study. Furthermore, leaching tests using RE minerals in the considered aqueous systems, i.e., acid leaching using $\mathrm{H}_{2} \mathrm{SO}_{4}, \mathrm{HCl}$ and $\mathrm{HNO}_{3}$, were performed to provide experimental data for comparison with theoretical findings from the corresponding Eh-pH diagrams.

Using $1 \mathrm{M}$ inorganic acid concentrations at $25^{\circ} \mathrm{C}$ with $10 \mathrm{~g} / \mathrm{L}$ solid concentration, the Ce recovery from bastnaesite leaching showed over $90 \%$ recovery in the $1 \mathrm{M}$ sulfuric acid and $1 \mathrm{M}$ nitric acid leaching systems, whereas $1 \mathrm{M}$ hydrochloric acid provided about $75 \%$ leaching recovery. The Eh- $\mathrm{pH}$ diagrams of REEs associated with bastnaesite leaching in the Ce-F-SO $-\mathrm{SO}_{2} \mathrm{O}$ system indicate that $\mathrm{Ce}$ has a strong affinity for $\mathrm{SO}_{4}{ }^{2-}$ and forms a Ce-SO 4 complex, under the excess $\mathrm{SO}_{4}{ }^{2-}$. It was interpreted from the modified Eh-pH diagram and the speciation plot that, in bastnaesite leaching using $1 \mathrm{M} \mathrm{H}_{2} \mathrm{SO}_{4}$, Ce mainly existed 
in ionic $\left(\mathrm{Ce}^{3+}\right)$ form, which resulted in a high leaching recovery of Ce. However, it might form $\mathrm{Ce}\left(\mathrm{SO}_{4}\right)_{2}$ pentahydrate under strongly oxidative conditions.

Under the same leaching conditions, Ce in monazite showed leaching recoveries lower than $1 \%$, regardless of the acid type. The Eh-pH diagrams of monazite indicate that Ce can stably exist as $\mathrm{Ce}^{3+}$ in both $\mathrm{HCl}$ and $\mathrm{HNO}_{3}$ systems. However, the leaching recovery of $\mathrm{Ce}$ in these two solutions was lower than $1 \%$. A possible reason for the low Ce recovery in monazite may be the passivation effect by other insoluble species formed during leaching, such as $\mathrm{NdPO}_{4}$ and $\mathrm{LaPO}_{4}$. In addition, the strong crystallinity of monazite minerals indicates that more intensive leaching conditions, such as higher temperature and stronger acidity, may be required to chemically decompose the monazite structure and promote the Ce recovery.

Yttrium leaching recovery from xenotime showed that sulfuric acid is a preferential leaching reagent with a relatively higher $\mathrm{Y}$ recovery (over 15\%) compared to nitric and hydrochloric systems. The Eh-pH diagrams of xenotime in leaching solutions indicate that $\mathrm{Y}$ has some solubility in the $\mathrm{H}_{2} \mathrm{SO}_{4}$ solution under oxidative and highly acidic conditions, which results in the highest recovery among the three lixiviants tested.

According to the Eh-pH diagrams of contaminating elements in the three leaching systems, Fe is likely to form precipitants under specific conditions and block the surface of minerals, thereby inhibiting the recovery of other REEs during leaching. It is suggested that the leaching recovery can be enhanced in the stability regions where Fe and other contaminating elements exist in ionic forms.

The compilation of thermodynamic data (Gibbs free energy) of possible RE mineral species reported in the literature presented the hypothesis that such differences were the result of variations in the crystallinity of REE mineral forms.

Author Contributions: Conceptualization, P.L. and J.M.W.; methodology, P.L.; software, P.L.; validation, P.L.; formal analysis, P.L. and X.Y.; investigation, P.L.; writing—original draft preparation, P.L.; writing-review and editing, J.M.W., X.Y. and R.Q.H.; funding acquisition, R.Q.H. All authors have read and agreed to the published version of the manuscript.

Funding: This research was funded by the Department of Energy of United States (DOE-FE0029900), project titled "Recovery of Rare Earth Elements from Coal Byproducts: Characterization and Laboratory- Scale Separation Tests". This report was prepared as an account of work sponsored by an agency of the United States Government. Neither the United States Government nor any agency thereof, nor any of their employees, makes any warranty, express or implied, or assumes any legal liability or responsibility for the accuracy, completeness or usefulness of any information, apparatus, product or process disclosed, or represents that its use would not infringe privately owned rights. Reference herein to any specific commercial product, process or service by trade name, trademark, manufacturer or otherwise does not necessarily constitute or imply its endorsement, recommendation or favoring by the United States Government or any agency thereof. The views and opinions of authors expressed herein do not necessarily state or reflect those of the United States Government or any agency thereof.

Institutional Review Board Statement: Not applicable.

Informed Consent Statement: Not applicable.

Data Availability Statement: Data sharing not applicable.

Conflicts of Interest: The authors declare no conflict of interest.

\section{Appendix A}

The thermodynamic data of the involved species was compiled from the HSC database and supplemented from other available resources, as shown in Table 1. 
Table 1. Thermodynamic data from the HSC software and other literatures [10,34-43].

\begin{tabular}{|c|c|c|c|c|c|}
\hline Species & $\begin{array}{c}\Delta G_{f, 298}^{0} \\
\text { (kcal/mol) }\end{array}$ & References & Species & $\begin{array}{c}\Delta G_{f, 298}^{0} \\
\text { (kcal/mol) }\end{array}$ & References \\
\hline $\mathrm{H}_{2} \mathrm{O}$ & -56.678 & HSC 5.11 & $\mathrm{LaF}_{3}$ & -388.093 & HSC 9.9 \\
\hline $\mathrm{P}$ & 0.000 & HSC 9.9 & $\mathrm{La}_{2} \mathrm{O}_{2} \mathrm{SO}_{4}$ & -511.334 & HSC 9.9 \\
\hline $\mathrm{H}_{3} \mathrm{PO}_{4}$ & -267.428 & HSC 9.9 & $\mathrm{LaS}$ & -107.728 & HSC 9.9 \\
\hline $\mathrm{HPO}_{3}{ }^{2-}$ & -193.968 & HSC 9.9 & $\mathrm{LaS}_{2}$ & -146.785 & HSC 9.9 \\
\hline \multirow[t]{2}{*}{$\mathrm{HPO}_{4}^{2-}$} & -261.949 & HSC 9.9 & $\mathrm{La}_{2} \mathrm{~S}_{3}$ & -288.790 & HSC 9.9 \\
\hline & -260.296 & HSC 5.11 & $\mathrm{La}_{2}\left(\mathrm{SO}_{4}\right)_{3}$ & -859.824 & HSC 9.9 \\
\hline $\mathrm{H}_{2} \mathrm{PO}_{3}^{-}$ & -202.326 & HSC 9.9 & & -859.291 & HSC 5.11 \\
\hline \multirow[t]{2}{*}{$\mathrm{H}_{2} \mathrm{PO}_{4}^{-}$} & -271.786 & HSC 9.9 & $\mathrm{La}_{2}\left(\mathrm{SO}_{4}\right)_{3} \cdot 9 \mathrm{H}_{2} \mathrm{O}$ & -1380.146 & HSC 9.9 \\
\hline & -270.126 & HSC 5.11 & & -1399.880 & Dean \\
\hline \multirow[t]{2}{*}{$\mathrm{PO}_{4}{ }^{3-}$} & -245.098 & HSC 9.9 & $\mathrm{La}_{2}\left(\mathrm{SO}_{4}\right)_{3}(\mathrm{a})$ & -877.762 & HSC 5.11 \\
\hline & -243.364 & HSC 5.11 & $\mathrm{LaF}^{2+}$ & -236.572 & HSC 9.9 \\
\hline $\mathrm{HF}(\mathrm{l})$ & -65.91 & HSC 9.9 & $\mathrm{LaF}_{2}^{+}$ & -307.773 & HSC 9.9 \\
\hline $\mathrm{F}^{-}$ & -67.3294 & HSC 9.9 & $\mathrm{LaF}_{4}^{-}$ & -447.461 & HSC 9.9 \\
\hline $\mathrm{HF}_{2}^{-}$ & -139.495 & HSC 9.9 & $\mathrm{LaSO}_{4}^{+}$ & -346.908 & HSC 9.9 \\
\hline S & 0.000 & HSC 9.9 & $\mathrm{La}\left(\mathrm{SO}_{4}\right)_{2}{ }^{-}$ & -526.596 & HSC 9.9 \\
\hline $\mathrm{SO}_{3}(\mathrm{l})$ & -89.3045 & HSC 9.9 & $\mathrm{La}_{2}\left(\mathrm{CO}_{3}\right)_{3}$ & -750.900 & Brookins \\
\hline $\mathrm{H}_{2} \mathrm{SO}_{4}$ & -164.894 & HSC 9.9 & & & \\
\hline $\mathrm{SO}_{3}$ & -88.1433 & HSC 9.9 & $\mathrm{Nd}$ & 0.000 & HSC 9.9 \\
\hline $\mathrm{HS}^{-}$ & 2.9063 & HSC 9.9 & $\mathrm{NdH}_{2}$ & -38.120 & HSC 9.9 \\
\hline $\mathrm{HSO}_{3}{ }^{-}$ & -126.103 & HSC 9.9 & $\mathrm{NdN}$ & -66.489 & HSC 9.9 \\
\hline \multirow[t]{2}{*}{$\mathrm{HSO}_{4}^{-}$} & -180.524 & HSC 9.9 & $\mathrm{Nd}_{2} \mathrm{O}_{3}$ & -411.102 & HSC 9.9 \\
\hline & -180.609 & HSC 5.11 & & -411.300 & Brookins \\
\hline $\mathrm{SO}_{3}^{2-}$ & -116.287 & HSC 9.9 & & -411.436 & HSC 5.11 \\
\hline $\mathrm{SO}_{4}^{2-}$ & -177.907 & HSC 9.9 & $\mathrm{Nd}(\mathrm{OH})_{3}$ & -306.629 & HSC 9.9 \\
\hline $\mathrm{HClO}_{4}(\mathrm{l})$ & 18.646 & HSC 9.9 & & -305.200 & Brookins \\
\hline $\mathrm{Cl}^{-}$ & -31.372 & HSC 9.9 & & -305.308 & Baes and Mesmer \\
\hline $\mathrm{Cl}_{3}^{-}$ & 65.864 & HSC 9.9 & $\mathrm{NdPO}_{4}$ & -442.053 & HSC 9.9 \\
\hline $\mathrm{ClO}^{-}$ & -8.668 & HSC 9.9 & & -439.200 & Liu and Byrne \\
\hline $\mathrm{ClO}_{2}^{-}$ & 4.108 & HSC 9.9 & & -423.461 & HSC 5.11 \\
\hline $\mathrm{ClO}_{3}^{-}$ & -1.886 & HSC 9.9 & $\mathrm{Nd}\left(\mathrm{PO}_{3}\right)_{3}$ & -766.726 & HSC 9.9 \\
\hline $\mathrm{ClO}_{4}^{-}$ & -1.886 & HSC 9.9 & $\mathrm{NdPO}_{4} \cdot 2 \mathrm{H}_{2} \mathrm{O}$ & -566.731 & HSC 9.9 \\
\hline $\mathrm{PCl}_{3}(\mathrm{l})$ & -65.496 & HSC 9.9 & $\mathrm{Nd}^{2+}$ & -100.198 & HSC 9.9 \\
\hline $\mathrm{POCl}_{3}(\mathrm{l})$ & -134.790 & HSC 9.9 & $\mathrm{Nd}^{3+}$ & -160.205 & HSC 9.9 \\
\hline $\mathrm{PCl}_{4}$ & -83.145 & HSC 9.9 & & -160.500 & Brookins \\
\hline $\mathrm{PCl}_{5}$ & -78.147 & HSC 9.9 & & -160.100 & HSC 5.11 \\
\hline $\mathrm{HN}_{3}(\mathrm{l})$ & 78.216 & HSC 9.9 & $\mathrm{Nd}^{4+}$ & -47.031 & HSC 9.9 \\
\hline $\mathrm{HNO}_{3}(\mathrm{l})$ & -19.300 & HSC 9.9 & $\mathrm{NdHPO}_{4}^{+}$ & -427.460 & Poitrasson \\
\hline $\mathrm{NH}_{3}(\mathrm{l})$ & -0.217 & HSC 9.9 & $\mathrm{Nd}\left(\mathrm{HPO}_{4}\right)_{2}^{-}$ & -692.500 & Poitrasson \\
\hline $\mathrm{NH}_{4} \mathrm{OH}(\mathrm{l})$ & -60.710 & HSC 9.9 & $\mathrm{NdH}_{2} \mathrm{PO}_{4}{ }^{2+}$ & -433.937 & HSC 9.9 \\
\hline $\mathrm{NH}_{3}$ & -0.566 & HSC 9.9 & & -433.510 & Poitrasson \\
\hline $\mathrm{NH}_{4} \mathrm{OH}$ & -52.381 & HSC 9.9 & $\mathrm{NdNO}_{3}{ }^{2+}$ & -188.223 & HSC 9.9 \\
\hline $\mathrm{NH}_{4} \mathrm{NO}_{3}$ & -43.921 & HSC 9.9 & $\mathrm{NdO}^{+}$ & -203.068 & HSC 9.9 \\
\hline $\mathrm{NH}_{4} \cdot \mathrm{H}_{2} \mathrm{PO}_{4}$ & -289.399 & HSC 9.9 & $\mathrm{NdO}_{2}^{-}$ & -218.630 & HSC 9.9 \\
\hline $\mathrm{NH}_{4}^{+}$ & -18.977 & HSC 9.9 & $\mathrm{NdOH}^{2+}$ & -206.797 & HSC 9.9 \\
\hline $\mathrm{NO}_{3}^{-}$ & -26.489 & HSC 9.9 & & -206.410 & HSC 5.11 \\
\hline \multirow[t]{2}{*}{$\mathrm{HNO}_{2}^{-}$} & 11.221 & HSC 9.9 & $\mathrm{Nd}(\mathrm{OH})_{2}{ }^{+}$ & -250.800 & Baes and Mesmer \\
\hline & & HSC 9.9 & $\mathrm{Nd}(\mathrm{OH})_{4}^{-}$ & -336.700 & Brookins \\
\hline $\mathrm{Ce}$ & 0.000 & HSC 9.9 & & -336.610 & Baes and Mesmer \\
\hline $\mathrm{CeH}_{2}$ & -35.731 & HSC 9.9 & $\mathrm{Nd}_{2}(\mathrm{OH})_{2}{ }^{4+}$ & -415.451 & Baes and Mesmer \\
\hline \multirow[t]{3}{*}{$\mathrm{CeO}_{2}$} & -245.301 & HSC 9.9 & $\mathrm{NdCl}_{2}$ & -154.111 & HSC 9.9 \\
\hline & -244.400 & Wagman & $\mathrm{NdCl}_{3}$ & -230.804 & HSC 9.9 \\
\hline & -244.900 & HSC 5.11 & $\mathrm{NdCl}_{3} \cdot 6 \mathrm{H}_{2} \mathrm{O}$ & -583.064 & HSC 9.9 \\
\hline \multirow[t]{2}{*}{$\mathrm{Ce}_{2} \mathrm{O}_{3}$} & -411.587 & HSC 9.9 & $\mathrm{NdOCl}$ & -225.415 & HSC 9.9 \\
\hline & -407.800 & Brookins & $\mathrm{NdCl}^{2+}$ & -192.530 & HSC 9.9 \\
\hline
\end{tabular}


Table 1. Cont.

\begin{tabular}{|c|c|c|c|c|c|}
\hline Species & $\begin{array}{c}\Delta G_{f, 298}^{0} \\
\text { (kcal/mol) }\end{array}$ & References & Species & $\begin{array}{c}\Delta G_{f, 298}^{0} \\
\text { (kcal/mol) }\end{array}$ & References \\
\hline \multirow[t]{3}{*}{$\mathrm{Ce}(\mathrm{OH})_{3}$} & -307.247 & HSC 9.9 & $\mathrm{NdCl}_{2}{ }^{+}$ & -223.435 & HSC 9.9 \\
\hline & -303.600 & Brookins & $\mathrm{NdCl}_{4}^{-}$ & -285.157 & HSC 9.9 \\
\hline & -303.490 & Baes and Mesmer & $\mathrm{Nd}_{2}\left(\mathrm{SO}_{4}\right)_{3}$ & -847.843 & HSC 5.11 \\
\hline \multirow[t]{3}{*}{$\mathrm{CePO}_{4}$} & -432.959 & HSC 9.9 & $\mathrm{NdSO}_{4}{ }^{+}$ & -343.500 & HSC 5.11 \\
\hline & -439.796 & Liu and Byrne & $\mathrm{Nd}\left(\mathrm{SO}_{4}\right)_{2}^{-}$ & -523.379 & HSC 5.11 \\
\hline & -421.750 & Byrne and Kim & $\mathrm{Nd}_{2}\left(\mathrm{SO}_{4}\right)_{3} \cdot 8 \mathrm{H}_{2} \mathrm{O}$ & -1335.000 & HSC 5.11 \\
\hline $\mathrm{CePO}_{4} \cdot 2 \mathrm{H}_{2} \mathrm{O}$ & -545.820 & HSC 9.9 & $\mathrm{Nd}_{2}\left(\mathrm{CO}_{3}\right)_{3}$ & -741.400 & Brookins \\
\hline $\mathrm{Ce}^{2+}$ & -74.898 & HSC 9.9 & & & \\
\hline \multirow[t]{2}{*}{$\mathrm{Ce}^{3+}$} & -162.105 & HSC 9.9 & Th & 0.000 & HSC 9.9 \\
\hline & -160.600 & Brookins & $\mathrm{ThH}_{2}$ & -25.527 & HSC 9.9 \\
\hline \multirow[t]{2}{*}{$\mathrm{Ce}^{4+}$} & -121.348 & HSC 9.9 & $\mathrm{Th}\left(\mathrm{HPO}_{4}\right)_{2} \cdot 4 \mathrm{H}_{2} \mathrm{O}$ & -952.667 & HSC 9.9 \\
\hline & -120.440 & Wagman & $\mathrm{Th}\left(\mathrm{NO}_{3}\right)_{4}$ & -250.762 & HSC 9.9 \\
\hline \multirow[t]{2}{*}{$\mathrm{CeH}_{2} \mathrm{PO}_{4}^{2+}$} & -435.081 & HSC 9.9 & $\mathrm{Th}\left(\mathrm{NO}_{3}\right)_{4} \cdot 4 \mathrm{H}_{2} \mathrm{O}$ & -500.379 & HSC 9.9 \\
\hline & -433.904 & HSC 5.11 & $\mathrm{Th}\left(\mathrm{NO}_{3}\right)_{4} \cdot 5 \mathrm{H}_{2} \mathrm{O}$ & -555.786 & HSC 9.9 \\
\hline $\mathrm{CeNO}_{3}{ }^{2+}$ & -189.025 & HSC 9.9 & ThO & -138.800 & HSC 9.9 \\
\hline $\mathrm{CeO}^{+}$ & -205.111 & HSC 9.9 & $\mathrm{ThO}_{2}$ & -279.455 & HSC 9.9 \\
\hline $\mathrm{CeO}_{2}^{-}$ & -217.402 & HSC 9.9 & & -279.340 & Wagman \\
\hline \multirow[t]{2}{*}{$\mathrm{CeOH}^{2+}$} & -209.611 & HSC 9.9 & & -278.330 & HSC 5.11 \\
\hline & -205.960 & HSC 5.11 & $\mathrm{Th}(\mathrm{OH})_{4}$ & -382.263 & HSC 9.9 \\
\hline \multirow[t]{2}{*}{$\mathrm{CeOH}^{3+}$} & -178.830 & HSC 9.9 & $\mathrm{Th}^{4+}$ & -168.507 & HSC 9.9 \\
\hline & -178.580 & Baes and Mesmer & & -168.520 & Wagman \\
\hline $\mathrm{Ce}(\mathrm{OH})_{2}^{2+}$ & -224.250 & HSC 9.9 & & -167.800 & HSC 5.11 \\
\hline $\mathrm{Ce}_{2}(\mathrm{OH})_{2}^{4+}$ & -413.410 & Baes and Mesmer & $\mathrm{ThHPO}_{4}^{2+}$ & -401.224 & HSC 9.9 \\
\hline $\mathrm{Ce}_{3}(\mathrm{OH})_{5}{ }^{4+}$ & -719.496 & Baes and Mesmer & $\mathrm{ThH}_{2} \mathrm{PO}_{4}^{2+b}$ & -434.174 & HSC 9.9 \\
\hline $\mathrm{Ce}(\mathrm{OH})_{2}^{2+}$ & -235.670 & Baes and Mesmer & & -723.550 & HSC 5.11 \\
\hline $\mathrm{Ce}_{2}(\mathrm{OH})_{2}{ }^{6+}$ & -362.070 & Baes and Mesmer & $\mathrm{ThH}_{2} \mathrm{PO}_{4}^{3+}$ & -446.378 & HSC 9.9 \\
\hline $\mathrm{Ce}_{2}(\mathrm{OH})_{3}{ }^{5+}$ & -419.430 & Baes and Mesmer & & -446.150 & HSC 5.11 \\
\hline $\mathrm{CeClO}_{4}^{2+}$ & -166.270 & HSC 9.9 & $\mathrm{ThH}_{3} \mathrm{PO}_{4}^{4+}$ & -445.706 & HSC 9.9 \\
\hline $\mathrm{CeF}_{3}$ & -385.311 & HSC 9.9 & & -444.030 & HSC 5.11 \\
\hline $\mathrm{CeF}_{4}$ & -418.999 & HSC 9.9 & $\mathrm{Th}\left(\mathrm{HPO}_{4}\right)_{3}^{2-}$ & -1001.906 & HSC 9.9 \\
\hline $\mathrm{CeS}$ & -107.259 & HSC 9.9 & $\mathrm{Th}\left(\mathrm{H}_{3} \mathrm{PO}_{4}\right)\left(\mathrm{H}_{2} \mathrm{PO}_{4}\right)^{3+}$ & -722.489 & HSC 5.11 \\
\hline $\mathrm{CeS}_{2}$ & -145.208 & HSC 9.9 & $\mathrm{Th}\left(\mathrm{HPO}_{4}\right)_{2} \cdot 4 \mathrm{H}_{2} \mathrm{O}$ & -952.667 & HSC 5.11 \\
\hline $\mathrm{Ce}_{2} \mathrm{~S}_{3}$ & -279.743 & HSC 9.9 & $\mathrm{Th}_{2}\left(\mathrm{PO}_{4}\right)_{2}\left(\mathrm{HPO}_{4}\right) \cdot \mathrm{H}_{2} \mathrm{O}$ & -1230.166 & Kerdaniel \\
\hline $\mathrm{Ce}_{3} \mathrm{~S}_{4}$ & -388.652 & HSC 9.9 & $\mathrm{ThO}^{+}$ & -204.534 & HSC 9.9 \\
\hline \multirow[t]{2}{*}{$\mathrm{Ce}\left(\mathrm{SO}_{4}\right)_{2}$} & -506.184 & HSC 9.9 & $\mathrm{ThOH}^{3+}$ & -220.070 & HSC 9.9 \\
\hline & -506.366 & HSC 5.11 & & -220.000 & Wagman \\
\hline \multirow[t]{2}{*}{$\mathrm{Ce}_{2}\left(\mathrm{SO}_{4}\right)_{3}$} & -860.943 & HSC 9.9 & & -220.069 & HSC 5.11 \\
\hline & -861.115 & HSC 5.11 & $\mathrm{Th}(\mathrm{OH})_{2}{ }^{2+}$ & -272.693 & HSC 9.9 \\
\hline $\mathrm{Ce}\left(\mathrm{SO}_{4}\right)_{2} \cdot 5 \mathrm{H}_{2} \mathrm{O}$ & -1191.210 & HSC 9.9 & & -272.680 & Wagman \\
\hline $\mathrm{Ce}_{2}\left(\mathrm{SO}_{4}\right)_{3} \cdot 8 \mathrm{H}_{2} \mathrm{O}(\mathrm{s})^{\mathrm{a}}$ & -1322.620 & Dean, Wagman & $\mathrm{Th}(\mathrm{OH})_{3}{ }^{+}$ & -322.711 & HSC 9.9 \\
\hline $\mathrm{CeF}^{2+}$ & -234.692 & HSC 9.9 & $\mathrm{Th}_{2}(\mathrm{OH})_{2}{ }^{6+}$ & -444.241 & HSC 9.9 \\
\hline $\mathrm{CeF}_{2}^{+}$ & -306.163 & HSC 9.9 & & -441.241 & HSC 5.11 \\
\hline $\mathrm{CeF}_{4}^{-}$ & -446.467 & HSC 9.9 & $\mathrm{Th}(\mathrm{OH})_{6}^{2-}$ & -445.000 & Wagman \\
\hline \multirow[t]{2}{*}{$\mathrm{CeSO}_{4}^{+}$} & -344.445 & HSC 9.9 & $\mathrm{Th}_{4}(\mathrm{OH})_{8}^{8+}$ & -1099.168 & HSC 5.11 \\
\hline & -344.627 & HSC 5.11 & $\mathrm{Th}_{4}(\mathrm{OH})_{12}{ }^{4+}$ & -1312.614 & Rand \\
\hline \multirow[t]{3}{*}{$\mathrm{Ce}\left(\mathrm{SO}_{4}\right)_{2}{ }^{-}$} & -523.696 & HSC 9.9 & $\mathrm{Th}_{6}(\mathrm{OH})_{14}{ }^{10+}$ & -1747.287 & Rand \\
\hline & -523.878 & HSC 5.11 & $\mathrm{Th}_{6}(\mathrm{OH})_{15}{ }^{9+}$ & -1811.602 & HSC 5.11 \\
\hline & & & $\mathrm{Th}_{2}(\mathrm{OH})_{3}^{5+}$ & -495.755 & Rand \\
\hline $\mathrm{La}$ & 0.000 & HSC 9.9 & $\mathrm{ThCl}_{2}$ & -161.045 & HSC 9.9 \\
\hline $\mathrm{LaH}_{2}$ & -38.415 & HSC 9.9 & $\mathrm{ThCl}_{3}$ & -213.197 & HSC 9.9 \\
\hline $\mathrm{LaN}$ & -64.779 & HSC 9.9 & $\mathrm{ThCl}_{4}$ & -261.724 & HSC 9.9 \\
\hline \multirow[t]{2}{*}{$\mathrm{La}_{2} \mathrm{O}_{3}$} & -407.239 & HSC 9.9 & $\mathrm{ThOCl}_{2}$ & -276.399 & HSC 9.9 \\
\hline & -407.700 & Brookins & $\mathrm{ThCl}^{3+}$ & -201.623 & HSC 9.9 \\
\hline
\end{tabular}


Table 1. Cont.

\begin{tabular}{|c|c|c|c|c|c|}
\hline Species & $\begin{array}{c}\Delta G_{f, 298}^{0} \\
\text { (kcal/mol) }\end{array}$ & References & Species & $\begin{array}{c}\Delta G_{f, 298}^{0} \\
\text { (kcal/mol) }\end{array}$ & References \\
\hline $\mathrm{LaO}_{2} \mathrm{H}$ & -239.621 & HSC 9.9 & $\mathrm{Th}\left(\mathrm{SO}_{4}\right)_{2}(\mathrm{a})$ & -537.701 & HSC 5.11 \\
\hline \multirow[t]{3}{*}{$\mathrm{La}(\mathrm{OH})_{3}$} & -305.945 & HSC 9.9 & $\mathrm{ThSO}_{4}{ }^{2+}$ & -353.900 & Wagman \\
\hline & -305.800 & Brookins & & -354.099 & HSC 5.11 \\
\hline & -305.745 & HSC 5.11 & $\mathrm{Th}\left(\mathrm{SO}_{4}\right)_{3}{ }^{2-}$ & -713.840 & Rand \\
\hline \multirow{3}{*}{$\mathrm{LaPO}_{4}$} & -442.238 & HSC 9.9 & $\mathrm{Th}\left(\mathrm{SO}_{4}\right)_{2} \cdot 9 \mathrm{H}_{2} \mathrm{O}$ & -1045.540 & Rand \\
\hline & -441.887 & Liu and Byrne & & & \\
\hline & -425.785 & HSC 5.11 & $\mathrm{Y}$ & 0.000 & HSC 9.9 \\
\hline $\mathrm{La}\left(\mathrm{PO}_{3}\right)_{3}$ & -764.090 & HSC 9.9 & YN & -64.165 & HSC 9.9 \\
\hline $\mathrm{LaPO}_{4} \cdot 2 \mathrm{H}_{2} \mathrm{O}$ & -569.549 & HSC 9.9 & $\mathrm{YH}_{2}$ & -43.233 & HSC 9.9 \\
\hline $\mathrm{La}^{2+}$ & -77.666 & HSC 9.9 & $\mathrm{YH}_{3}$ & -49.328 & HSC 9.9 \\
\hline \multirow[t]{3}{*}{$\mathrm{La}^{3+}$} & -163.997 & HSC 9.9 & $\mathrm{Y}_{2} \mathrm{O}_{3}$ & -434.061 & HSC 9.9 \\
\hline & -163.400 & Brookins & & -434.200 & Brookins \\
\hline & -164.010 & HSC 5.11 & $\mathrm{Y}(\mathrm{OH})_{3}$ & -319.870 & HSC 9.9 \\
\hline $\mathrm{LaH}_{2} \mathrm{PO}_{4}^{2+}$ & -437.575 & HSC 9.9 & & -308.600 & Brookins \\
\hline $\mathrm{LaNO}_{3}^{2+}$ & -191.232 & HSC 9.9 & $\mathrm{YPO}_{4}$ & -446.402 & HSC 9.9 \\
\hline $\mathrm{LaO}^{+}$ & -204.935 & HSC 9.9 & $\mathrm{YPO}_{4} \cdot 2 \mathrm{H}_{2} \mathrm{O}$ & -552.328 & HSC 9.9 \\
\hline $\mathrm{LaO}_{2}^{-}$ & -216.948 & HSC 9.9 & YS & -108.884 & HSC 9.9 \\
\hline $\mathrm{LaOH}^{2+}$ & -209.524 & HSC 9.9 & $\mathrm{Y}_{2} \mathrm{~S}_{3}$ & -296.898 & HSC 9.9 \\
\hline $\mathrm{La}_{2}(\mathrm{OH})_{2}{ }^{4+}$ & -416.286 & Baes and Mesmer & $\mathrm{Y}_{2}\left(\mathrm{SO}_{4}\right)_{3} \cdot 8 \mathrm{H}_{2} \mathrm{O}$ & -1320.595 & HSC 9.9 \\
\hline $\mathrm{La}_{3}(\mathrm{OH})_{5}{ }^{4+}$ & -721.350 & Baes and Mesmer & $\mathrm{Y}^{3+}$ & -163.788 & HSC 9.9 \\
\hline $\mathrm{LaCl}_{2}$ & -109.004 & HSC 9.9 & & -165.800 & Brookins \\
\hline $\mathrm{LaCl}_{3}$ & -237.904 & HSC 9.9 & $\mathrm{YO}^{+}$ & -198.099 & HSC 9.9 \\
\hline $\mathrm{LaCl}_{3} \cdot 7 \mathrm{H}_{2} \mathrm{O}$ & -645.182 & HSC 9.9 & $\mathrm{YO}_{2}^{-}$ & -227.335 & HSC 9.9 \\
\hline $\mathrm{LaOCl}$ & -230.090 & HSC 9.9 & $\mathrm{YOH}^{2+}$ & -209.927 & HSC 9.9 \\
\hline $\mathrm{LaCl}^{2+}$ & -195.747 & HSC 9.9 & $\mathrm{YSO}_{4}^{+}$ & -347.459 & HSC 9.9 \\
\hline $\mathrm{LaCl}_{2}^{+}$ & -226.743 & HSC 9.9 & $\mathrm{Y}\left(\mathrm{SO}_{4}\right)_{2}^{-}$ & -526.127 & HSC 9.9 \\
\hline \multirow[t]{6}{*}{$\mathrm{LaCl}_{4}^{-}$} & -288.371 & HSC 9.9 & $\mathrm{Y}(\mathrm{OH})_{4}^{-}$ & -341.200 & Brookins \\
\hline & & & $\mathrm{YCl}_{3}$ & -221.713 & HSC 9.9 \\
\hline & & & $\mathrm{YCl}_{3} \cdot 6 \mathrm{H}_{2} \mathrm{O}$ & -591.468 & HSC 9.9 \\
\hline & & & $\mathrm{YOCl}$ & -225.617 & HSC 9.9 \\
\hline & & & $\mathrm{YCl}^{2+}$ & -198.520 & HSC 9.9 \\
\hline & & & $\mathrm{Y}_{2}\left(\mathrm{CO}_{3}\right)_{3}$ & -752.400 & Brookins \\
\hline
\end{tabular}

\section{References}

1. Chelgani, S.C.; Rudolph, M.; Leistner, T.; Gutzmer, J.; Peuker, U.A. A review of rare earth minerals flotation: Monazite and xenotime. Int. J. Min. Sci. Technol. 2015, 25, 877-883. [CrossRef]

2. Binnemans, K.; Jones, P.T.; Blanpain, B.; van Gerven, T.; Yang, Y.; Walton, A.; Buchert, M. Recycling of rare earths: A critical review. J. Clean. Prod. 2013, 51, 1-22. [CrossRef]

3. Massari, S.; Ruberti, M. Rare earth elements as critical raw materials: Focus on international markets and future strategies. Resour. Policy 2013, 38, 36-43. [CrossRef]

4. Schulze, R.; Buchert, M. Estimates of global REE recycling potentials from NdFeB magnet material. Resour. Conserv. Recycl. 2016, 113, 12-27. [CrossRef]

5. Sun, Z.; Xiao, Y.; Agterhuis, H.; Sietsma, J.; Yang, Y. Recycling of metals from urban mines-A strategic evaluation. J. Clean. Prod. 2016, 112, 2977-2987. [CrossRef]

6. Yang, Y.; Walton, A.; Sheridan, R.; Güth, K.; Gauß, R.; Gutfleisch, O.; Buchert, M.; Steenari, B.-M.; van Gerven, T.; Jones, P.T.; et al. REE Recovery from End-of-Life NdFeB Permanent Magnet Scrap: A Critical Review. J. Sustain. Met. 2017, 3, 122-149. [CrossRef]

7. Ippolito, N.; Belardi, G.; Piga, L. Determination of mineralogical composition of spent fluorescent powders by coupling ICPspectroscopy and electronic microprobe analyses. TrAC Trends Anal. Chem. 2017, 94, 14-20. [CrossRef]

8. Jha, M.K.; Kumari, A.; Panda, R.; Kumar, J.R.; Yoo, K.; Lee, J.Y. Review on hydrometallurgical recovery of rare earth metals. Hydrometallurgy 2016, 165, 2-26. [CrossRef]

9. Pourbaix, M. Atlas of Electrochemical Equilibria in Aqueous Solutions; NACE International: Houston, TX, USA, 1966.

10. Brookins, D.G. Eh-pH Diagrams for Geochemistry; Springer Science \& Business Media: Berlin/Heidelberg, Germany, 2012; ISBN 3642730930.

11. Hayes, S.A.; Yu, P.; O'Keefe, T.J.; O'Keefe, M.J.; Stoffer, J.O. The Phase Stability of Cerium Species in Aqueous Systems. J. Electrochem. Soc. 2002, 149, C623-C630. [CrossRef] 
12. Kim, E.; Osseo-Asare, K. Aqueous stability of thorium and rare earth metals in monazite hydrometallurgy: Eh-pH diagrams for the systems Th-, $\mathrm{Ce}-, \mathrm{La}-, \mathrm{Nd}-\left(\mathrm{PO}_{4}\right)-\left(\mathrm{SO}_{4}\right)-\mathrm{H}_{2} \mathrm{O}$ at $25^{\circ} \mathrm{C}$. Hydrometallurgy 2012, 113, 67-78. [CrossRef]

13. Shuai, G.; Zhao, L.; Wang, L.; Long, Z.; Cui, D. Aqueous stability of rare earth and thorium elements during hydrochloric acid leaching of roasted bastnaesite. J. Rare Earths 2017, 35, 1255-1260. [CrossRef]

14. Al-Nafai, I.S. Application of Pourbaix Diagrams in the Hydrometallurgical Processing of Bastnasite; The Pennsylvania State University: University Park, PA, USA, 2015.

15. Agarwal, V.; Safarzadeh, M.S.; Galvin, J. Solvent extraction and separation of Y(III) from sulfate, nitrate and chloride solutions using PC88A diluted in kerosene. Miner. Process. Extr. Met. Rev. 2017, 39, 258-265. [CrossRef]

16. Dai, S.; Graham, I.T.; Ward, C.R. A review of anomalous rare earth elements and yttrium in coal. Int. J. Coal Geol. 2016, 159, 82-95. [CrossRef]

17. Hower, J.C.; Granite, E.J.; Mayfield, D.B.; Lewis, A.S.; Finkelman, R.B. Notes on contributions to the science of rare earth element enrichment in coal and coal combustion byproducts. Minerals 2016, 6, 32. [CrossRef]

18. Franus, W.; Wiatros-Motyka, M.M.; Wdowin, M. Coal fly ash as a resource for rare earth elements. Environ. Sci. Pollut. Res. 2015, 22, 9464-9474. [CrossRef]

19. Eskenazy, G.M. Rare earth elements in a sampled coal from the Pirin deposit, Bulgaria. Int. J. Coal Geol. 1987, 7, 301-314. [CrossRef]

20. Dai, S.; Hower, J.C.; Ward, C.R.; Guo, W.; Song, H.; O’Keefe, J.M.K.; Xie, P.; Hood, M.M.; Yan, X. Elements and phosphorus minerals in the middle Jurassic inertinite-rich coals of the Muli Coalfield on the Tibetan Plateau. Int. J. Coal Geol. 2015, 144-145, 23-47. [CrossRef]

21. Finkelman, R.B.; Dai, S.; French, D. The importance of minerals in coal as the hosts of chemical elements: A review. Int. J. Coal Geol. 2019, 212, 103251. [CrossRef]

22. Yang, X.; Werner, J.; Honaker, R. Leaching of rare Earth elements from an Illinois basin coal source. J. Rare Earths 2019, 37, 312-321. [CrossRef]

23. Rozelle, P.L.; Khadilkar, A.B.; Pulati, N.; Soundarrajan, N.; Klima, M.S.; Mosser, M.M.; Miller, C.E.; Pisupati, S.V. A Study on Removal of Rare Earth Elements from U.S. Coal Byproducts by Ion Exchange. Metall. Mater. Trans. E 2016, 3, 6-17. [CrossRef]

24. Moldoveanu, G.A.; Papangelakis, V.G. An overview of rare-earth recovery by ion-exchange leaching from ion-adsorption clays of various origins. Mineral. Mag. 2016, 80, 63-76. [CrossRef]

25. Kumari, A.; Panda, R.; Jha, M.K.; Kumar, J.R.; Lee, J.Y. Process development to recover rare earth metals from monazite mineral: A review. Miner. Eng. 2015, 79, 102-115. [CrossRef]

26. US Department of Energy. Report on Rare Earth Elements from Coal and Coal Byproducts; US Department of Energy: Washington, DC, USA, 2017; pp. 1-49.

27. Zhang, W.; Yang, X.; Honaker, R.Q. Association characteristic study and preliminary recovery investigation of rare earth elements from Fire Clay seam coal middlings. Fuel 2018, 215, 551-560. [CrossRef]

28. Yang, F.; Kubota, F.; Baba, Y.; Kamiya, N.; Goto, M. Selective extraction and recovery of rare earth metals from phosphor powders in waste fluorescent lamps using an ionic liquid system. J. Hazard. Mater. 2013, 254-255, 79-88. [CrossRef]

29. Reed, D.W.; Fujita, Y.; Daubaras, D.L.; Jiao, Y.; Thompson, V.S. Bioleaching of rare earth elements from waste phosphors and cracking catalysts. Hydrometallurgy 2016, 166, 34-40. [CrossRef]

30. Peelman, S.; Sun, Z.H.I.; Sietsma, J.; Yang, Y. Leaching of Rare Earth Elements: Review of Past and Present Technologies; Elsevier Inc.: Amsterdam, The Netherlands, 2015; ISBN 9780128023280.

31. Dahle, J.T.; Arai, Y. Environmental Geochemistry of Cerium: Applications and Toxicology of Cerium Oxide Nanoparticles. Int. J. Environ. Res. Public Heal. 2015, 12, 1253-1278. [CrossRef] [PubMed]

32. Chaudhuri, N.K.; Sawant, R.M.; Ramakumar, K.L. Correlation of the Stability Constants of the Aqueous Fluoride Complexes of Lanthanides. Rev. Inorg. Chem. 2001, 21, 331-368. [CrossRef]

33. Bernardez, L.; Lima, L.D.A. Improved method for enumerating sulfate-reducing bacteria using optical density. MethodsX 2015, 2, 249-255. [CrossRef]

34. Dean, J.A. Lange's Handbook of Chemistry; McGraw-Hill: New York, NY, USA, 1999; ISBN 0070163847.

35. Wagman, D.D.; Evans, W.H.; Parker, V.B.; Schumm, R.H.; Halow, I.; Bailey, S.M.; Churney, K.L.; Nuttall, R.L. The NBS Tables of Chemical Thermodynamic Properties: Selected Values for Inorganic and C1 and C2 Organic Substances in SI Units; Defense Technical Information Center: Fort Belvoir, VA, USA, 1982.

36. Baes, C.F.; Mesmer, R.E. The thermodynamics of cation hydrolysis. Am. J. Sci. 1981, 281, 935-962. [CrossRef]

37. Rand, M. Chemical Thermodynamics of Thorium. In Chemical Thermodynamics; Mompean, F.J., Perrone, J., Illemassène, M., Eds.; OECD: Paris, France, 2007; Volume 11.

38. Poitrasson, F.; Oelkers, E.; Schott, J.; Montel, J.-M. Experimental determination of synthetic $\mathrm{NdPO}_{4}$ monazite end-member solubility in water from $21^{\circ} \mathrm{C}$ to $300{ }^{\circ} \mathrm{C}$ : Implications for rare earth element mobility in crustal fluids. Geochim. Cosmochim. Acta 2004, 68, 2207-2221. [CrossRef]

39. Kerdaniel, E.D.F.D.; Clavier, N.; Dacheux, N.; Terra, O.; Podor, R. Actinide solubility-controlling phases during the dissolution of phosphate ceramics. J. Nucl. Mater. 2007, 362, 451-458. [CrossRef]

40. Liu, X.; Byrne, R.H. Rare earth and yttrium phosphate solubilities in aqueous solution. Geochim. Cosmochim. Acta 1997, 61, 1625-1633. [CrossRef] 
41. Byrne, R.H.; Kim, K.-H. Rare earth precipitation and coprecipitation behavior: The limiting role of PO43- on dissolved rare earth concentrations in seawater. Geochim. Cosmochim. Acta 1993, 57, 519-526. [CrossRef]

42. Roine, A. HSC Chemistry ${ }^{\circledR}$, version 5.1; Outotec: Pori, Finland, 2002.

43. Roine, A. HSC Chemistry ${ }^{\circledR}$, version 9.9; Outotec: Pori, Finland, 2019. 